j

\title{
AVAILABILITY AND QUALITY OF WATER FROM UNDERGROUND COAL MINES IN
} H JOHNSON AND MARTIN COUNTIES, KENTUCKY s

U.S. GEOLOGICAL SURVEY

Water-Resoufoes tavestigations -81-690

OPRN evt

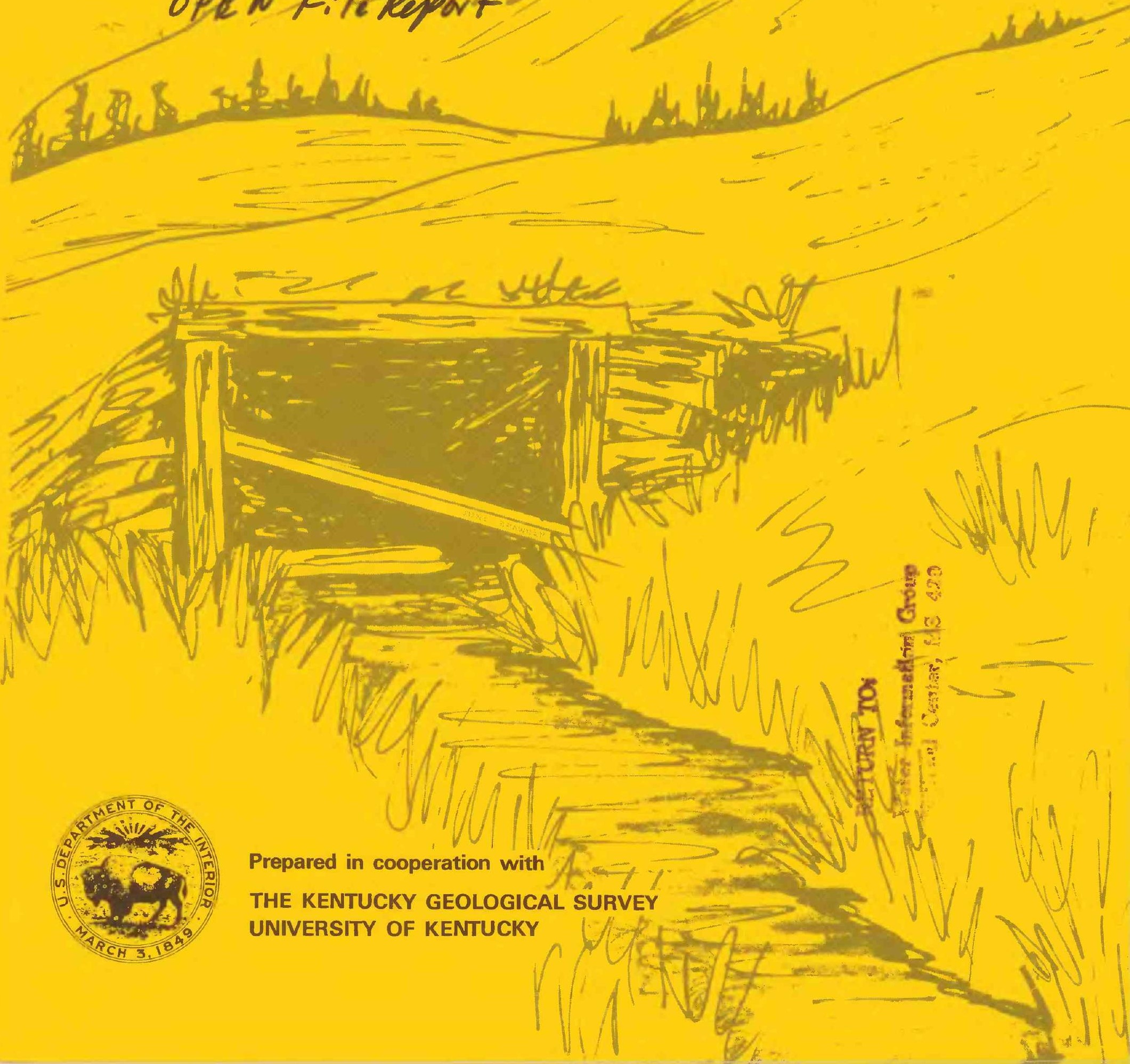



AVAILABILITY AND QUALITY OF WATER FROM UNDERGROUND

COAL MINES IN JOHNSON AND MARTIN COUNTIES, KENTUCKY

By D. S. Mull, U.S. Geological Survey

Steven Cordiviola and Dennis W. Risser, Kentucky Geological Survey

U.S. GEOLOGICAL SURVEY

OYEN f IIE
Water-Resources Investigations $81-690$

Prepared in cooperation with

THE KENTUCKY GEOLOGICAL SURVEY

UNIVERSITY OF KENTUCKY 
UNITED STATES DEPARTMENT OF THE INTERIOR

JAMES G. WATT, Secretary

GEOLOGICAL SURVEY

Doyle G. Frederick, Acting Director

For additional information write to:

U.S. Geological Survey

Room 572 Federa1 Building

Louisville, Kentucky 40202 


\section{CONTENTS}

Page

Factors for converting inch-pound units to metric (SI) units...... VIII

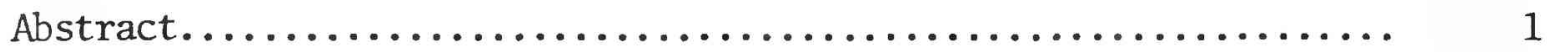

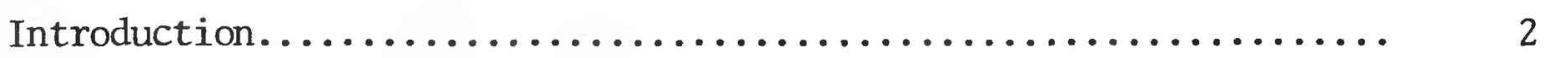

Purpose and scope.............................. 2

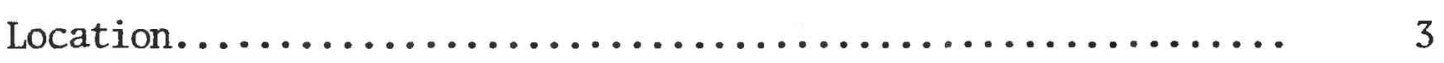

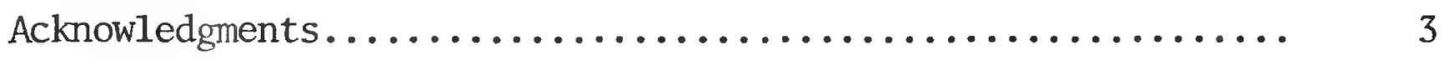

Methods of investigation......................... 3

Physiography and geology $\ldots \ldots \ldots \ldots \ldots \ldots \ldots \ldots \ldots \ldots \ldots \ldots \ldots \ldots$

Occurrence of water in underground coal mines.............. 10

Precipitation....................................... 10

Recharge area.............................. 10

Rock fractures related to depth to mining horizon......... 10

Relation of mine opening to dip of coal seam........... 12

Effect of mine location above or below drainage.......... 14

Evaluating the water-supply potential of underground mines....... 14

Mines above drainage......................... 19

Mines below drainage.......................... 27

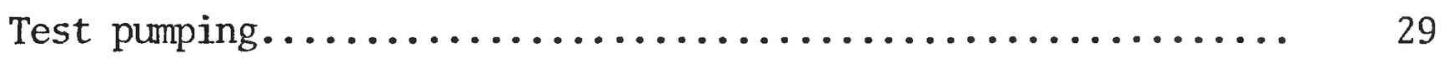

Results of test pumping at site $5 \ldots \ldots \ldots \ldots \ldots \ldots \ldots . \ldots . . . . .29$

Results of test pumping at site $58 \ldots \ldots \ldots \ldots \ldots . \ldots . . . . . .34$ 


\section{CONTENTS--Continued}

\section{Page}

Quality of water in coal mines.............................. 34

General water quality from all mines.............. 34

Comparison of water quality from coal mines

above and below drainage...................... 41

Variability of mine-water quality $\ldots \ldots \ldots \ldots \ldots \ldots \ldots \ldots \ldots, 43$

Effects of flow variations on water quality......... 43

Effects of pumping on water quality............. 46

Development of water supply from underground mines.......... 46

Summary.......................................... 48

Selected references.............................. 50 


\section{ILLUSTRATIONS}

(P1ates are in pocket)

Plate 1. Map showing location of coal mines, Irvine-Paint Creek

Fault, and chemical character of water from selected

mines in Johnson County, Kentucky.

2. Map showing location of coal mines, Warfield Fault, and chemical character of water from selected mines in Martin County, Kentucky.

Figure 1. Map showing Johnson and Martin Counties within the Eastern Kentucky Coal Field.................. 4

2. Generalized columnar section showing major coal

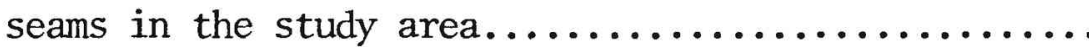

3. Graph of mean monthly precipitation at Paintsville, Кy., 1941-70..................... 11

4. Sketch showing the occurrence of water in slope mines, drift mines and vertical shafts............

5. Hydrograph of discharge from sites 21 and 22 and precipitation for the period May 15, 1977

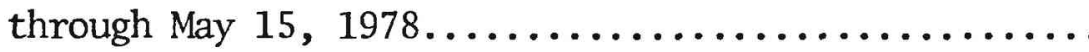

6. Graph of relation of mine size to total discharge

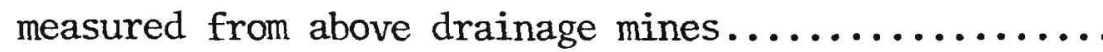

7. Graph of range of average discharge for mines

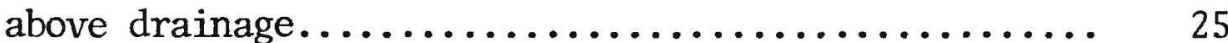

8. Graph of time-drawdown relation for test pumping at site 5 , Sept. $20,1977$. 


\section{ILLUSTRATIONS - -Continued}

Figure 9. Hydrograph of water levels at site 5 after test

pumping, Sept. 20, 1977, precipitation, and

stage of the Tug Fork at Kermit, W. Va............

10. Hydrograph of water levels at site 5 after test

pumping, March 6, 1978, precipitation, and

stage of the Tug Fork at Kermit, W. Va...........

11. Graph of mean dissolved constituents concentration

in water from mines above and below drainage.......

12. Graph of relation between specific conductance

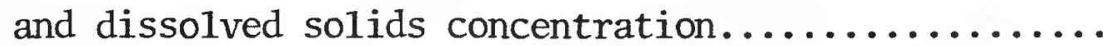

13. Graph of relation between specific conductance and discharge at site $21 \ldots \ldots \ldots \ldots \ldots \ldots \ldots \ldots$

14. Graph showing chemical quality of water before and after pumping at site $5 \ldots \ldots \ldots \ldots \ldots \ldots \ldots$ 
Table 1. Mine-water sampling sites in Martin County.......... 5

2. Mine-water sampling sites in Johnson County.......... 6

3. Field measurements of mine discharge, specific conductance, and $\mathrm{pH}$ in Martin County............ 15

4. Field measurements of mine discharge, specific conductance, and $\mathrm{pH}$ in Johnson County........... 16

5. Maximum, minimum, and mean discharges calculated as sum of discharges from all entries for selected above-drainage mines............. 22

6. Calculation of mine discharge as percent of precipitation on land surface above mine..........

7. Above-drainage mines with best water-

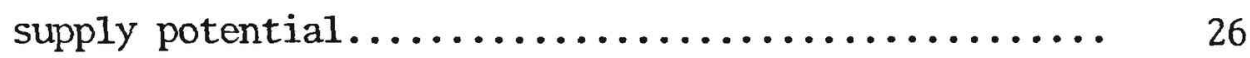

8. Below-drainage mines with best water-

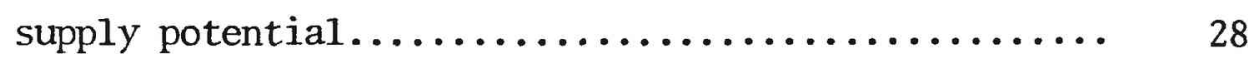

9. Chemical analyses of mine water from selected

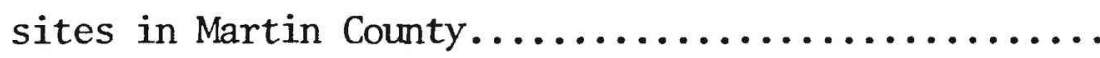

10. Chemical analyses of mine water from selected

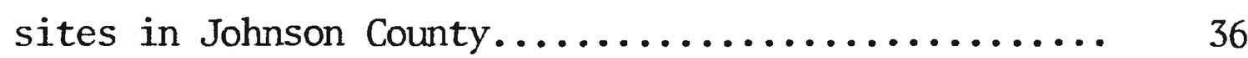

11. Maximum, minimum, and median values of water characteristics for all samples............... 38

12. Source and significance of dissolved-mineral constituents and physical properties of

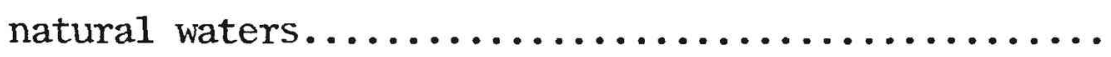


Data in this report are given in inch-pound units. To convert inchpound units to metric (SI) units, the following conversion factors are used:

\begin{tabular}{|c|c|c|}
\hline Multiply inch-pound & By & To obtain metric units \\
\hline inch (in) & 25.4 & millimeters (mm) \\
\hline foot $(f t)$ & $\int .3048$ & meters (m) \\
\hline mile & 1.609 & kilometers (km) \\
\hline square mile & 2.590 & square kilometers $\left(\mathrm{km}^{2}\right)$ \\
\hline gallon & 3.785 & 1iters (L) \\
\hline million gallons (Mgal) & $3.785 \times 10^{-3}$ & cubic hectometers $\left(\mathrm{hm}^{3}\right)$ \\
\hline $\begin{array}{l}\text { gallon per minute } \\
\text { (gal/min) }\end{array}$ & $6.309 \times 10^{-2}$ & 1iters per second $(\mathrm{L} / \mathrm{s})$ \\
\hline cubic foot per second $\left(\mathrm{ft}^{3} / \mathrm{s}\right)$ & .02832 & $\begin{array}{l}\text { cubic meters per second } \\
\left(\mathrm{m}^{3} / \mathrm{s}\right)\end{array}$ \\
\hline
\end{tabular}




\section{AVAILABILITY AND QUALITY OF WATER FROM \\ UNDERGROUND COAL MINES IN JOHNSON AND MARTIN COUNTIES, KENTUCKY}

By D. S. Mu11, U.S. Geologica1 Survey,

and

Steven Cordiviola and Dennis W. Risser, Kentucky Geological Survey

ABSTRACT

This report provides water users with detailed information on the location, quantity, and quality of water available from underground coal mines in the Breathitt Formation of Pennsylvanian age in part of eastern Kentucky. The principal coal seams mined are the Van Lear in Johnson County and the Alma in Martin County. Coal mines that contained water were located by field inventory and coal-mine maps .

The principal factors that affect the occurrence of water in coal mines are the size of the recharge area overlying the mine, the intensity and duration of precipitation, and the altitude of the mine relative to that of the nearest perennial stream.

Ten above-drainage mines (that is, mines at higher elevations than that of the nearest perennial stream) are considered potential sources of water. Discharge from these mines ranged from 12 to 1,700 gallons per minute. The highest sustained discharge from a mine ranged from 750 to 1,200 gallons per minute.

The water in coal mines is part of the hydrologic system and varies seasonally with precipitation. Annual discharge from most above-drainage mines ranged from 3 to 10 percent of annual precipitation on the landsurface area above the mine.

Eight below-drainage mines are considered potential sources of water. Two were test-pumped at rates of 560 to 620 gallons per minute for as 1ong as 6 hours. After test pumping the Warfield Mining No. 1 mine during September 1977 and March 1978, the recovery (or recharge) rates were significantly different. In September, the recharge rate was about 1,150 gallons per minute, but in March the recharge rate was 103,500 gallons per minute. This difference reflects the seasonal variations in the amount of water available to the ground-water system. Estimates of water stored in below-drainage mines ranged from 22 to 1,462 million gallons. This storage represents a safety factor sufficient to provide water through periods of limited recharge to the mine. 
Most mine water is of the calcium magnesium sulfate type. In general, water from below-drainage mines had lower concentrations of dissolved constituents and higher $\mathrm{pH}$ than water from mines above drainage. The hardness of water ranged from soft to very hard and $\mathrm{pH}$ ranged from 3.1 to 8.0 units. Dissolved iron ranged from 0.01 to 64 milligrams per liter. Phenol concentrations in water from eight coal mines ranged from 0 to 5 micrograms per liter.

There seems to be a significant difference in the chemical quality of water from above- and below-drainage mines. The concentration of most constituents was lower in water from below-drainage mines than it was from above-drainage mines.

The better quality water from below-drainage mines may reflect (1) lower mineralization resulting from less atmospheric oxygen available to react with pyrite or, (2) the result of sampling only the upper zones of water in below-drainage mines where the water has been diluted by less mineralized surface water or inflow or recharge.

\section{INTRODUCTION}

\section{Purpose and Scope}

The resurgence of coal mining, increased commercial and industrial activity, coupled with a general growth in population have increased the demands on existing water supplies of many communities in eastern Kentucky. Pursuant to the need for a dependable source of water, some communities, industries, and individuals have turned to coal mines for their water supply.

The purpose of this report is to provide information on the reliability, quality, and quantity of water available from underground coal mines. Johnson and Martin Counties, Kentucky were selected for a pilot project to evaluate coal mines as a source of water because of the abundance of coal mines in different stratigraphic units and topographic positions. This investigation is part of an on-going cooperative study of the water resources of Kentucky by the Kentucky Geological Survey, and the U.S. Geological Survey.

The scope of the report is limited to a discussion of those geologic and hydrologic factors that affect the occurrence and chemical quality of water in underground coal mines in Johnson and Martin Counties, Kentucky. Problems related to coal mining such as sedimentation, erosion and surfacewater quality are not within the scope of this report. 


\section{Location}

Johnson and Martin are adjoining counties located in the northeastern section of Kentucky's Eastern Coal Field (fig. 1). The two-county study area of about 495 squre miles, lies between latitudes $37^{\circ} 40^{\prime}$ and $38^{\circ} 00^{\prime}$ North and between longitudes $82^{\circ} 20^{\prime}$ and $83^{\circ} 00^{\prime}$ West. The Tug Fork of the Big Sandy River borders Martin County on the east and also forms the border between Kentucky and West Virginia.

\section{Acknowledgments}

The authors acknowledge the assistance of many residents in the study area, who allowed access to private property. Many coal mine owners and operators provided information on water conditions in their mines. Special thanks are extended to Mr. Roy Coleman who provided information on mining and furnished shelter for water-leve1-recording equipment near Warfield, Ky.

\section{Methods of Investigation}

Underground coal mines in the study area were located by field reconnaissance from 1975 through 1977. Initially, attempts were made to visit all mine openings shown on 7-1/2 minute topographic maps. However, these visits indicated that only the relatively large coal mines contained significant quantities of water. A search of mine maps at the Institute for Mining and Mineral Research, Lexington, Kentucky, revealed areas of large-scale mining activity and these areas were plotted on 7-1/2 minute topographic maps. The field reconnaissance then focused on these areas of large-scale mining. This approach shortened field time and eliminated visits to small, dry mines.

Access by addits, shafts, or slope entries to mines that contain water are located by site number on plates 1 and 2 . Tables 1 and 2 list the site number, location, mine name, coal seam mined, and the estimated volume of the mine for a11 mines inventoried in Johnson and Martin Counties. Note from tables 1 and 2 that in several mines, water is accessible through multiple openings each of which is designated by a separate site number.

To estimate the amounts of water available, discharge and water-level measurements were made at each mine opening. Storage and recharge capabilities of the mines were estimated by test pumping selected mines (sites 5 and 58).

The mine entry at site 5 was equipped with a water-stage mercury manometer coupled to an automatic digital recorder to record the recovery of water leve1 after test-pumping and natural variations of water leve 1 in the mine. Continuous water-stage recorders and V-notch weirs were installed at entries of two mines (sites 21 and 22) to provide continuous records of mine-water discharge. 

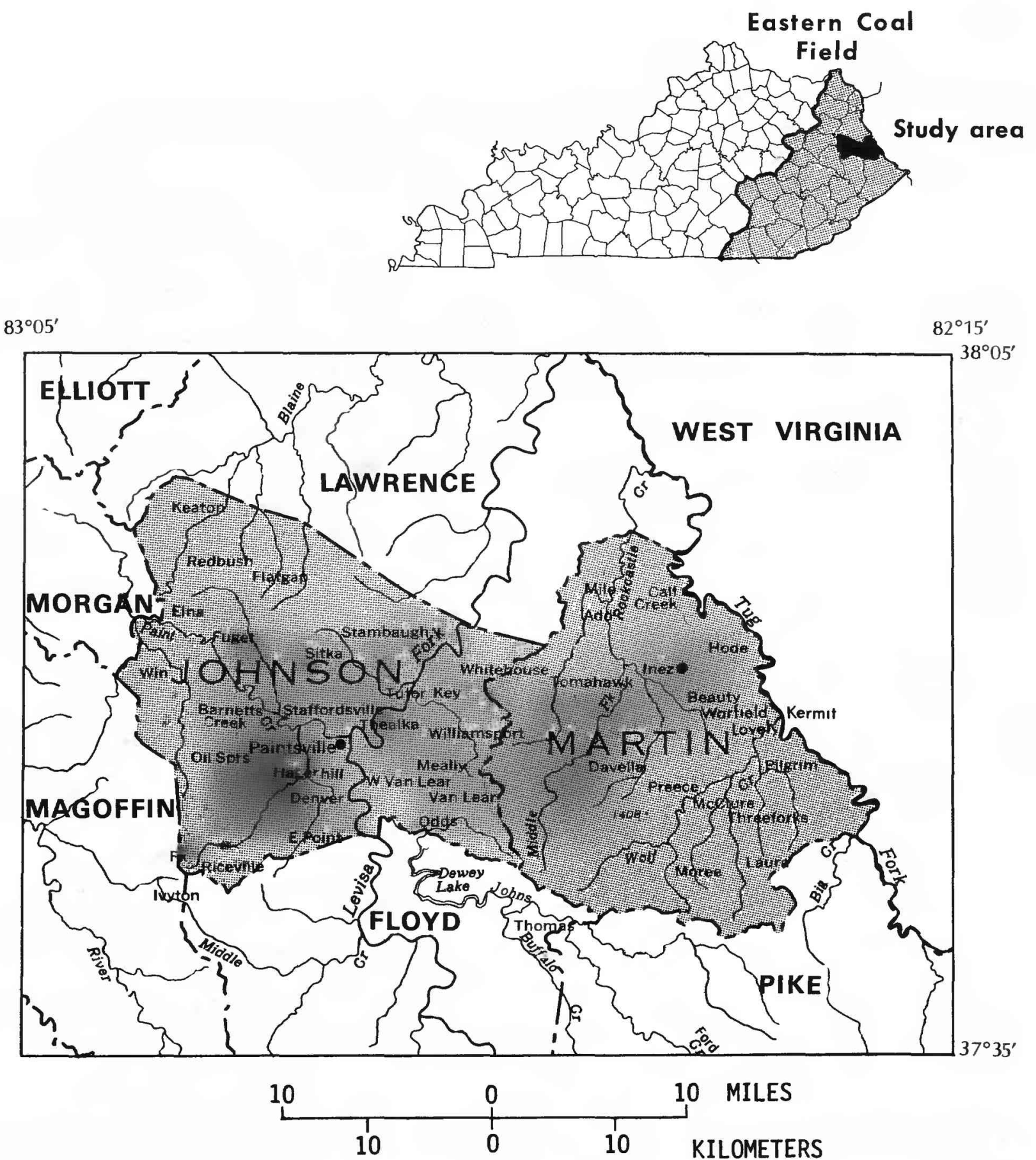

Figure 1. - Location of Johnson and Martin Counties, Eastern Kentucky Coal Field. 
Table 1.--Mine-water sampling sites in Martin County

\begin{tabular}{|c|c|c|c|c|c|c|}
\hline $\begin{array}{l}\text { Site } \\
\text { number }\end{array}$ & $\begin{array}{l}\text { Lati } \\
\text { longi }\end{array}$ & $\begin{array}{l}\text { tude } \\
\text { tude }\end{array}$ & Mine name & Seam mined & $\begin{array}{c}\text { Mine volumea/ } \\
\text { (million cubic feet) }\end{array}$ & $\begin{array}{l}\text { Date } \\
\text { abandoned }\end{array}$ \\
\hline 1 & 375028 & 822542 & Buck Creek Coal Co., Himmler..... & Alma & $195 \mathrm{~b} /$ & 1951 \\
\hline 2 & 375035 & 822458 & Buck Creek Coa1 Co., Coleman..... & .....do....... & $195 \underline{b} /$ & 1930 \\
\hline 3 & 375032 & 822504 & Buck Creek Coa1 Co., Ear1ston.... & .....do....... & $195^{\mathrm{b} /}$ & 1930 \\
\hline 4 & 375025 & 822450 & Collins Creek Coal Co., Sluss.... & .....do....... & $195^{b /}$ & 1961 \\
\hline 5 & 375047 & 822518 & Warfie1d Mining Co. No. 1....... & ....do....... & 5.7 & 1963 \\
\hline 6 & 374911 & 822406 & Wo1f Creek Collieries No. 3..... & .....do....... & 103 & 1977 \\
\hline 7 & 374805 & 822239 & ............ do.............. & .....do........ & 103 & 1977 \\
\hline 8 & 374839 & 822533 & Wolf Creek Collieries No. 4..... & .....do....... & 17 & 1965 \\
\hline 9 & 374849 & 822507 & Wolf Creek Collieries No. 2..... & .....do....... & 31 & Active \\
\hline 10 & 374838 & 822539 & Peter Cave Coal Co. No. 1....... & .....do....... & 85 & Active \\
\hline 11 & 375348 & 823529 & - & Unnamed & - & ? \\
\hline 12 & 375334 & 823520 & - & .....do........ & - & $?$ \\
\hline 13 & 375334 & 823529 & - & .....do....... & - & ? \\
\hline 14 & 375344 & 823537 & - & .....do....... & - & $?$ \\
\hline 15 & 375516 & 823200 & - & Broas & - & $?$ \\
\hline 16 & 374526 & 823143 & $\begin{array}{l}\text { Martin County Coa1 Co. No. } 1 \text {, } \\
\text { Coalburg. }\end{array}$ & Peach Orchard & 22 & Active \\
\hline 17 & 374447 & 823217 & $\begin{array}{l}\text { Martin County Coal Co. No. } 1 \text {, } \\
\text { Stockton. }\end{array}$ & Broas & 3.0 & 1972 \\
\hline 18 & 374446 & 823210 & $\begin{array}{l}\text { Martin County Coal Co. No. } 1 \text {, } \\
\text { Coalburg. }\end{array}$ & Peach Orchard & 22 & Active \\
\hline 19 & 374859 & 823900 & - & Peach Orchard & - & $?$ \\
\hline 20 & 375113 & 823538 & - & .... do....... & - & $?$ \\
\hline $20 a$ & 374332 & 823017 & Pontiki Coal Co. No. 1......... & Pond Creek & 6.0 & Active \\
\hline
\end{tabular}

\footnotetext{
a/ Volume of mine available for water storage calculated assuming a 5-foot thickness of coal removed over 50 percent of the areal extent of the mine.

b/ Himmler, Earlston, Coleman, and Sluss mines reportedly a11 interconnected.
} 
Table 2.--Mine-water sampling sites in Johnson County

\begin{tabular}{|c|c|c|c|c|c|c|}
\hline $\begin{array}{l}\text { Site } \\
\text { number }\end{array}$ & $\begin{array}{l}\text { Latit } \\
\text { longit }\end{array}$ & $\begin{array}{l}\text { tude } \\
\text { Lude }\end{array}$ & Mine namea/ & Seam mined & $\begin{array}{l}\text { Mine volume } \mathrm{b} / \\
\text { (million cubic feet) }\end{array}$ & $\begin{array}{l}\text { Date } \\
\text { abandoned }\end{array}$ \\
\hline 21 & 375024 & 824737 & North East Coa1 Co. No. 1....... & Van Lear & 30 & 1930 \\
\hline 22 & 375035 & 824734 & North East Coal Co. No. 3........ & ...... do...... & $146 \mathrm{c} /$ & 1951 \\
\hline 23 & 375101 & 824654 & North East Coal Co. No. 4....... & ......do...... & 146 & 1930 \\
\hline 24 & 375056 & 824643 & 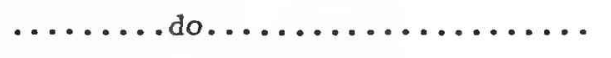 & .....do...... & 146 & 1930 \\
\hline 25 & 375059 & 824634 & 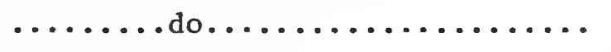 & ......do...... & 146 & 1930 \\
\hline 26 & 375030 & 824734 & North East Coal Co. No. 2....... & .....do...... & 59 & 1923 \\
\hline 27 & 375043 & 824613 & 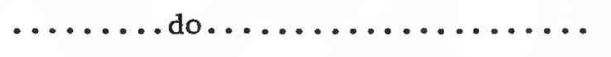 & ......do...... & 59 & 1923 \\
\hline 28 & 375029 & 824600 & 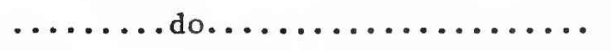 & ......do...... & 59 & 1923 \\
\hline 29 & 375038 & 824605 & 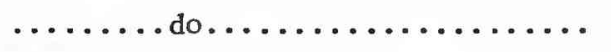 & ......do...... & 59 & 1923 \\
\hline 30 & 375027 & 824605 & 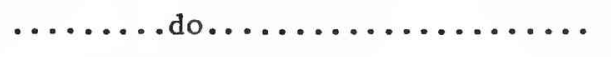 & .....do...... & 59 & 1923 \\
\hline 31 & 375025 & 824614 & 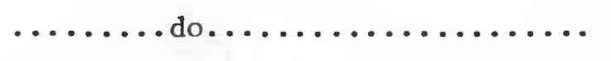 & ......do..... & 59 & 1923 \\
\hline 32 & 374944 & 824634 & - & .....do...... & - & $?$ \\
\hline 33 & 374951 & 824633 & - & ......do..... & - & $?$ \\
\hline 34 & 375052 & 824543 & North East Coal Co. No. $5 \ldots \ldots \ldots$ & ......do...... & 34 & 1951 \\
\hline 35 & 375052 & 824506 & 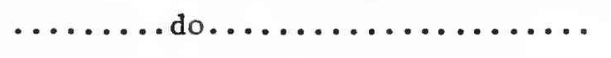 & ......do...... & 34 & 1951 \\
\hline 36 & 375055 & 824454 & 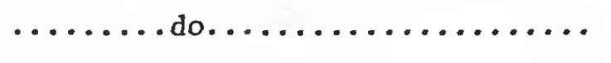 & .....do..... & 34 & 1951 \\
\hline 37 & 375104 & 824457 & 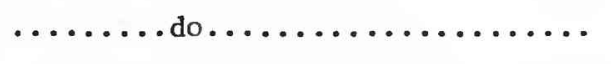 & ......do...... & 34 & 1951 \\
\hline 38 & 375102 & 824455 & 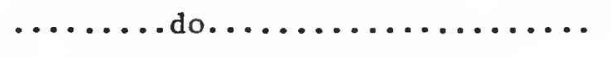 & ......do..... & 34 & 1951 \\
\hline 39 & 375122 & 824443 & 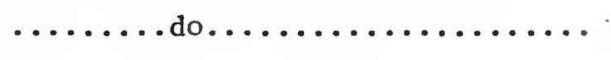 & ......do...... & 34 & 1951 \\
\hline 40 & 375035 & 824501 & - & .....do...... & - & $?$ \\
\hline 41 & 375032 & 824431 & Tutor Key Coal Co. No 1........ & ......do...... & 17 & 1964 \\
\hline 42 & 375129 & 824552 & Stambaugh Coal Co. No 1 and No. 2 & ......do...... & 3.2 & 1964 \\
\hline 43 & 375130 & 824539 & 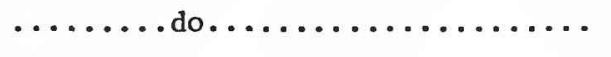 & .....do...... & 3.2 & 1964 \\
\hline 44 & 375129 & 824401 & White Ash Coal Co. No $4 \ldots . . . .$. & .....do..... & .6 & Active \\
\hline 45 & 375133 & 824401 & White Ash Coal Co. No. 3...... & .....do...... & .8 & 1976 \\
\hline 46 & 375158 & 824355 & White Ash Coal Co. No. 1....... & ...... do...... & 46 & Active \\
\hline 47 & 375212 & 824208 & $\begin{array}{l}\text { Miller's Creek Co-op Inc., White- } \\
\text { house mine. }\end{array}$ & .....do...... & 38 & 1956 \\
\hline 48 & 375112 & 824337 & Royal Collieries, Offutt mine... & ......do..... & 30 (est.) & 1938 \\
\hline 49 & 375032 & 824352 & - & ......do...... & - & $?$ \\
\hline 50 & 375002 & 824215 & - & ......do...... & - & $?$ \\
\hline
\end{tabular}


Table 2.--Mine-water sampling sites in Johnson County--Continued

\begin{tabular}{|c|c|c|c|c|c|c|}
\hline $\begin{array}{l}\text { Site } \\
\text { number }\end{array}$ & $\begin{array}{l}\text { Lat: } \\
\text { long }\end{array}$ & $\begin{array}{l}\text { tude } \\
\text { tude }\end{array}$ & Mine name $e^{a /}$ & Seam mined & $\begin{array}{c}\text { Mine volume } \\
\text { (million cubic feet) }\end{array}$ & $\begin{array}{l}\text { Date } \\
\text { abandoned }\end{array}$ \\
\hline 51 & 375122 & 824724 & Meade \& Castle Coal Co. No. 1... & Van Lear & .1 & 1955 \\
\hline 52 & 375125 & 824720 & - & .....do...... & - & $?$ \\
\hline 53 & 375655 & 824807 & - & .....do...... & - & $?$ \\
\hline 54 & 375244 & 824925 & Goose Fork Coal Co. No. 1...... & .....do...... & .9 & 1971 \\
\hline 55 & 375258 & 824923 & - & .....do...... & - & $?$ \\
\hline 56 & 375257 & 824919 & - & ......do...... & - & $?$ \\
\hline 57 & 375308 & 824900 & - & ......do...... & - & $?$ \\
\hline 58 & 375144 & 824937 & M \& P Coal Co. No. 1.......... & ......do...... & 8.3 & 1963 \\
\hline 59 & 375138 & 825007 & $\begin{array}{l}\text { Hagar Hill Mining Co. No. } 1 \text { and } \\
\text { No. } 2 \text {. }\end{array}$ & .....do....... & 9.5 & 1954 \\
\hline 60 & 375129 & 825024 & 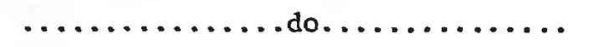 & .....do....... & 9.5 & 1954 \\
\hline 61 & 375102 & 825001 & - & .....do....... & - & $?$ \\
\hline 62 & 375054 & 825002 & - & .....do....... & - & $?$ \\
\hline 63 & 374552 & 825212 & - & .....do....... & - & $?$ \\
\hline 64 & 374700 & 824928 & - & .....do....... & - & $?$ \\
\hline 65 & 374753 & $82: 4546$ & - & .....do....... & - & $?$ \\
\hline 66 & 374756 & 824525 & William's Mining Co. No. 1...... & . ....do...... & 3.2 & 1953 \\
\hline 67 & 374747 & 824503 & - & .....do....... & - & $?$ \\
\hline 68 & 374751 & 824444 & Fitch Coa1 Co. No. 3............. & . .....do....... & 2.6 & 1955 \\
\hline 69 & 374748 & 824431 & 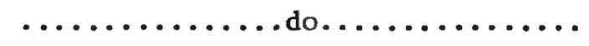 & .....do....... & 2.6 & 1955 \\
\hline 70 & 374752 & 824411 & Buffalo Creek Coal Co. No. 1..... & . ....do....... & .9 & 1961 \\
\hline 71 & 374638 & 824609 & - & .....do....... & - & $?$ \\
\hline 72 & 374638 & 824544 & Consolidation Coal Co. 151 - 155.. & .....do....... & 510 & 1949 \\
\hline 73 & 374610 & 824531 & We11, does not penetrate mine.... & - & - & $?$ \\
\hline 74 & 374444 & 824410 & Consolfdation Coal Co. $151-155 \ldots$ & - Van Lear & 510 & 1949 \\
\hline 75 & 374459 & 824254 & 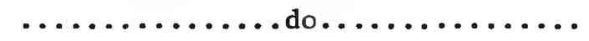 & .....do...... & 510 & 1949 \\
\hline 76 & 374636 & 824328 & $\ldots \ldots \ldots \ldots \ldots$. & . .... do....... & 510 & 1949 \\
\hline 77 & 374943 & 824814 & North East Coal Co. No. 1........ & .....do...... & 30 & 1930 \\
\hline 78 & 374458 & 824324 & North East Coa1 Co. No. 11 d/.... & .....do....... & 510 & 1949 \\
\hline
\end{tabular}

a/ Small truck mines which connect with large mines are listed under the mine name, size, and abandonment date of the major working.

b/ Volume of mine avallable for water storage calculated assuming a 5-foot thickness of coa1 removed for 50 percent of the areal extent of the mine.

c/ North East Coal Company's No. 3 and No. 4 mines are connected.

d/ Reportedly connected with Consolidation Coal Company's mines 151-155. 
At each site where water could be collected, field measurements of $\mathrm{pH}$, specific conductance, and temperature were made. Field measurements for $\mathrm{pH}$ were made with Hach* narrow-range colorimetric kits. Specific electrical conductance was measured with a Beckman* RB-3 meter. Forty-one water samples were collected for more complete chemical analysis from 27 sites. Repeat samples were collected at several sites to define the variation of chemical quality with seasonal changes in discharge. Eight samples were analyzed for phenol concentrations. Standard analytical methods of the U.S. Geological Survey (Brown, Skougstad, and Fishman, 1970) were used for all analyses.

\section{PHYSIOGRAPHY AND GEOLOGY}

Johnson and Martin Counties are located in Kentucky's Eastern Coal Field within the Kanawha Section of the Appalachian Plateaus physiographic province. The Kanawha Section is a highly dissected plateau characterized by narrow valleys, irregular steep-sided ridges, and generally rugged terrain (McFarlan, 1943). Maximum relief in the two-county area is 1,056 feet according to McGrain and Currens (1978).

The area is drained by a we11 integrated, dendritic system of small streams which flow into the Levisa and Tug Forks of the Big Sandy River. The drainage divide between Levisa Fork and Tug Fork is the boundary between Johnson and Martin County. Thus Johnson County is drained by Levisa Fork and Martin County is drained by Tug Fork.

The rocks which crop out in Johnson and Martin Counties are Pennsylvanian in age and consist primarily of coal-bearing rocks of the Breathitt Formation and the underlying Lee Formation. Rocks of the Lee Formation crop out only in the stream valleys of northern Johnson County.

The Breathitt Formation is about 1,800 feet thick, contains all the major coal seams in the study area, and consists of sandstone, siltstone, shale, coal, and underclay. Limestone is relatively rare in the Breathitt Formation. It occurs in shale as nodules and concretions 2-3 feet in diameter and locally forms discontinuous beds or lenses less than 2 feet thick in the Magoffin Member (Outerbridge, 1976).

The Lee Formation is about 300 feet thick and consists mainly of clean orthoquartzite sandstone with thin beds of shale, siltstone, and coal.

The relative position of major coal seams and lithology of rocks which crop out in the area are shown in the generalized stratigraphic column (fig. 2). Detailed stratigraphic columns and lithologic descriptions are given on each 7-1/2 minute geologic quadrangle map 1isted in the references.

*The use of brand names in this report is for identification purposes

only and does not imply endorsement by the U.S. Geological Survey. 


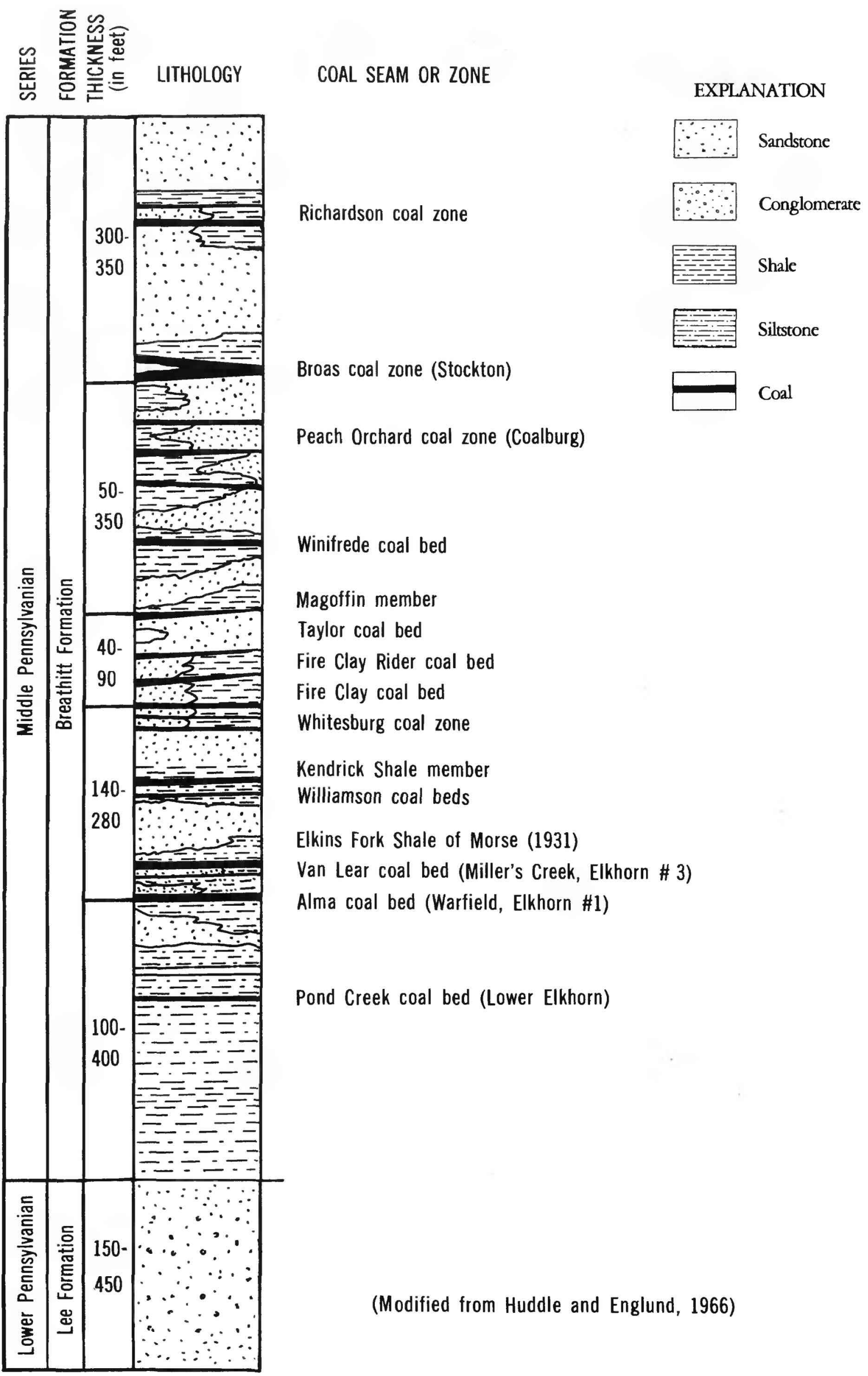

Figure 2.-- Generalized columnar section showing major coal seams in the study area. 
Structura1ly, rocks of the Breathitt Formation are affected by the Irvine-Paint Creek Fault in central Johnson County and the Warfield Fault in eastern Martin County. The Irvine-Paint Creek Fault is a normal fault and downthrown on the south (plate 1). The Warfield Fault also is a normal fault, downthrown on the north, and extends about two miles into the area near Lovely (plate 2). Although the rocks of the area are folded into broad anticlines and synclines, the dip of the rocks is very gently except in the vicinity of the faults where the dip is as much as eight degrees.

The coal seams of major economic importance in the study area are the Van Lear and Alma. The Van Lear seam has been mined extensively in Johnson County near Paintsville and the Alma has been mined primarily in Martin County near Warfield. Coal production was first reported from both counties in 1879. The total production from underground mines through 1975 exceeded 32 million tons for Johnson County and 25 million tons for Martin County (Currens and Smith, 1977).

\section{OCCURRENCE OF WATER IN UNDERGROUND COAL MINES}

The occurrence of water in underground coal mines is controlled by many factors. The principal factors are: (1) precipitation, (2) recharge area of the mine, (3) rock fractures (both natural and caused by roof collapse) related to depth to mining horizon, (4) relation of mine openings to dip of the coal seam and (5) position of the mine above or below drainage. The influence of these factors on the occurrence of water in underground mines is discussed below.

Precipitation.--A11 water in underground mines originates as precipitation which percolates downward to the mined-out areas. Only a small portion of water from a given rainfall percolates directly into an underground mine because some water runs off into streams, some evaporates, and some is used by plants. Precipitation is fairly evenly distributed throughout the year (fig. 3), but high evapotranspiration rates in spring and summer months reduce the volume of water available to percolate into the mines. Most precipitation percolates to the mines from about October to May, when most vegetation is dormant.

Recharge Area.--The recharge area to an underground mine is the land surface above the mine which acts as a catchment and infiltration area for precipitation. During the ground-water recharge season the amount of precipitation which can potentially infiltrate into a mine is largely a function of the size of the mine's recharge area. The recharge area of a mine may be larger than the areal extent of the underground workings, but generally the recharge area is approximately equal to the mine size.

Rock Fractures Related to Depth to Mining Horizon.--The character of the bedrock overburden and the depth to the mined zone below land surface control the quantity of water available to underground mines. In general, rocks of the Eastern Kentucky Coal Field have very low primary permeability, 


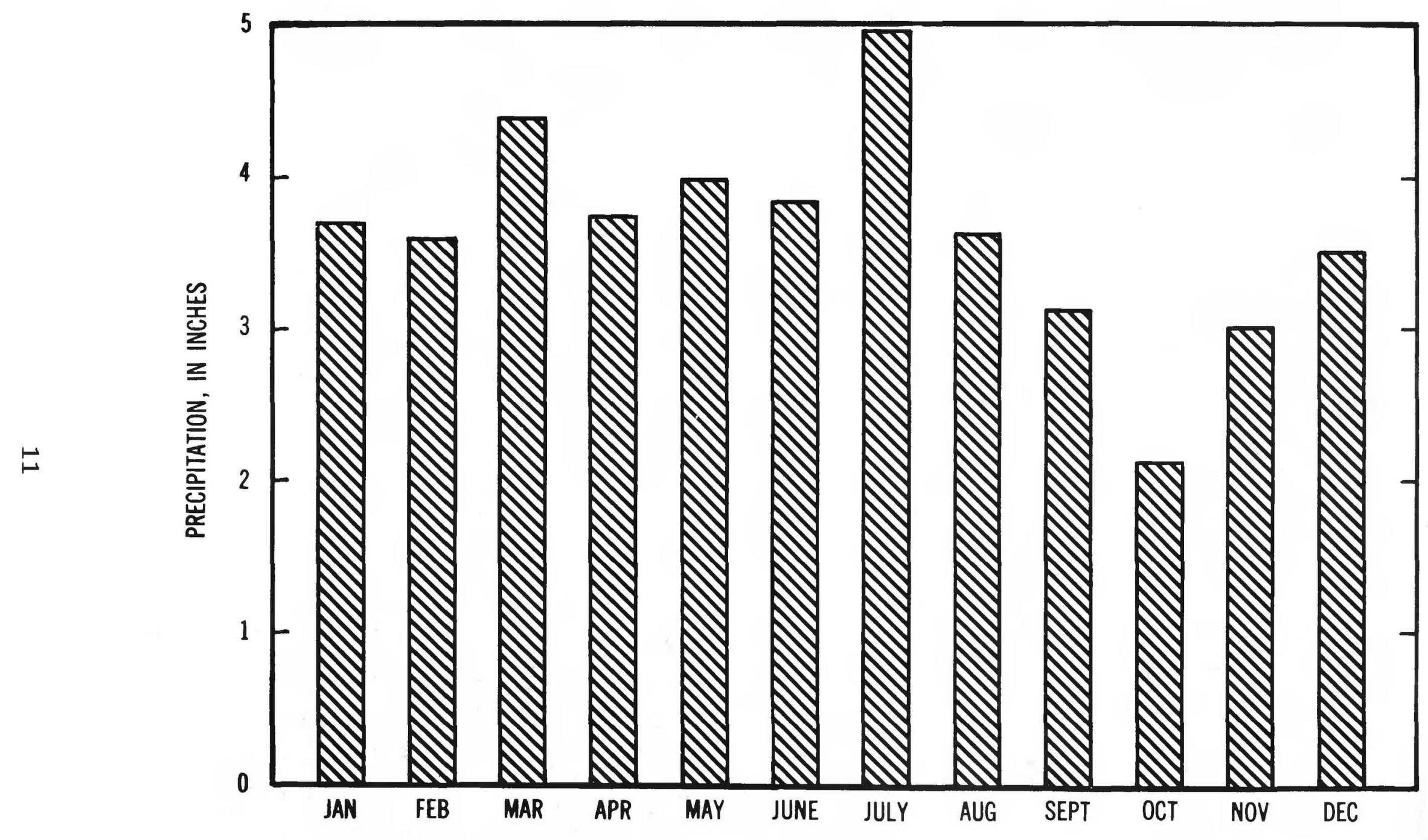

Figure 3. - Mean monthly precipitation at Paintsville, Kentucky, 1941-1970. 
thus most ground-water movement occurs in secondary fractures in the rocks (Price, Mul1, and Kilburn, 1962). Secondary permeability is enhanced in rocks overlying coal mines because roof collapse in mined-out areas causes fractures in the overlying rock which may extend to land surface. The extent of roof collapse and resulting fracturing is controlled to a large extent by the type of mining. Al1 underground mines in Johnson and Martin Counties were worked by the room and pillar methods in which coal is removed from rooms on a grid pattern and pillars of coal are left intact to support the roof and prevent land-surface subsidence. Prior to abandonment, pillars are usually removed and the roof is allowed to collapse.

Secondary fractures related to roof collapse are especially significant to vertical flow of water into the mined area and are controlled in part by the depth of the mine below land surface. If roof failure occurs within 150 feet of land surface, the amount of surface subsidence is approximately 50 percent of the thickness of the material removed from the mine (Davis, 1968). However, surface subsidence is only 25 to 30 percent of the thickness when roof failure is approximately 300 feet in depth.

In some mines the roof is supported by backfilling as the mining progresses. This technique reduces the likelihood of roof collapse and also reduces the space available for the storage or movement of water. However, it is likely that the mined areas continue to function as collection galleries because the backfill material is usually more permeable than the undisturbed rock.

Relation of Mine Openings to Dip of Coal Seam.--The relation between the location of the mine openings, and the dip of the coal beds and the occurrence of water in three different types of underground mine entries is shown on figure 4 .

Coal mines can be classified as drift, slope, or shaft mines based upon the type of entrance used to access the coal. A drift mine is used where a coal seam crops out on a hillside and the mine is worked directly into the outcrop. Water will discharge naturally or accumulate in the mine depending upon whether the mine was worked up or down the dip of the coal seam (fig. 4, examples 1 and 2). The drift mine is the most common type of coal mine in Johnson and Martin Counties because the hilly topography affords easy access to many coal seams. In cases where a coal seam is relatively close to the land surface, but cannot be reached by a drift mine, an inclined shaft which slopes down to the coal bed is used. This is called a slope mine (fig. 4, examples 4 and 5). When the coal bed lies some distance below the surface, a vertical shaft is used (fig. 4, examples 3 and 6). Although only one shaft mine was found in the study area, water samples were frequently collected from vertical ventilation shafts. Shaft and slope mines are typically used to mine coal below drainage. During active mining, water that accumulates in underground mines is removed by pumping or natural drainage. After abandonment, the water that fills the mine may drain from the mouth depending upon the position of the mine entrance relative to the dip of the coal seam. 


\section{EXPLANATION}

1. Drift mine - water ponded in mine

2. Drift mine - water flowing from portal

3. Air shaft - no flow

4. Slope mine flooded - no discharge from portal

5. Slope mine flooded - water flowing from portal

6. Air shaft - water flowing

\section{Not to scale}
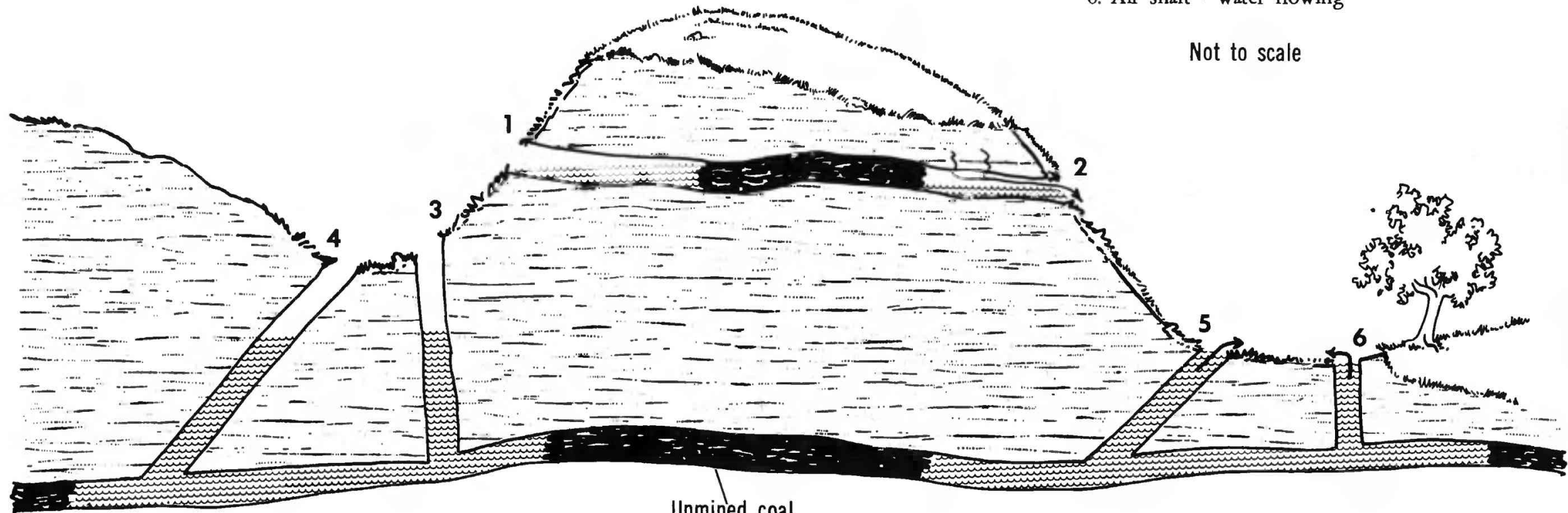

Unmined coal

Figure 4.- Occurrence of warer in slope mines, drift mines and vertical shafts. 
Effect of Mine Location Above or Below Drainage.--The location of mines relative to drainage is of major importance to the occurrence of water in the mines. For this report, mines are classed as below drainage if the mine galleries are at lower elevations than the nearest perennial stream. Mines worked below the level of perennial streams are usually below the regional water table. Thus, mines below drainage receive recharge from the surface and from ground water in the surrounding saturated rocks. The mines below drainage are almost always flooded because water accumulates in the mine. Usually there is no water discharge from the slope or shaft openings (fig. 4, examples 3 and 4). Under certain conditions however, water will flow from a shaft or slope opening provided the hydraulic head is great enough to cause the water in the mine to rise to land surface (fig. 4, examples 5 and 6).

\section{EVALUATING THE WATER-SUPPLY POTENTIAL OF UNDERGROUND COAL MINES}

The quality and quantity of water should be evaluated when planning to use a coal mine as a water supply. Although the quality of raw mine water may be undesirable, modern treatment procedures can usually produce water of acceptable quality for almost any use. Because the chemical quality of mine water usually can be improved by treatment, the primary factor is usually the quantity of water which the mine can dependably supply throughout the year.

The two most important hydrologic factors that must be known to evaluate a mine as a potential water supply are the water in storage and recharge rate. The volume of water in the mine is water in storage; the rate which water replenishes storage is the recharge rate. Obviously, a mine having both a large storage volume and rapid recharge rate will provide the most reliable water supply. A large storage volume provides a margin of safety against sudden increases in demand or seasonal fluctuations of recharge rate or both, and a rapid recharge rate will allow water to be replenished to the mine as it is used.

To define the seasonal variation of mine discharge, the discharge from selected mines in Johnson and Martin Counties shown on plates 1 and 2 was measured during the wet and dry season throughout the study period. These measurements are listed by site number and date of observation on tables 3 and 4.

Accurate evaluation of the storage and recharge characteristics of coal mines will vary considerably depending upon whether the mines are located above or below drainage. The water-supply characteristics of above-drainage mines can be determined in part by simply measuring water flowing from mine openings. However, below-drainage mines usually have no natural surface drainage and are more difficult to evaluate. The water-supply potential of below-drainage mines is discussed separately from mines above drainage in a following section. 
Table 3.--Field measurements of mine discharge, specific conductance and pH, Martin County

\begin{tabular}{|c|c|c|c|c|c|c|c|c|c|}
\hline Site & Date & $\begin{array}{l}\text { Discharge } \\
\text { (gal/min) }\end{array}$ & $\begin{array}{l}\text { Specific conductance } \\
\text { (micromhos per cm } \\
\text { at } 25^{\circ} \mathrm{C} \text { ) }\end{array}$ & $\underset{\text { (units) }}{\mathrm{pH}}$ & Site & Date & $\begin{array}{l}\text { Discharge } \\
(\mathrm{gal} / \mathrm{min})\end{array}$ & $\begin{array}{l}\text { Specific conductance } \\
\text { (micromhos per cm } \\
\text { at } 25^{\circ} \mathrm{C} \text { ) }\end{array}$ & $\begin{array}{c}\mathrm{pH} \\
\text { (units) }\end{array}$ \\
\hline \multirow[t]{5}{*}{1} & $8-12-75$ & $N F$ & 100 & 6.4 & 6 & $6-4-75$ & $-a /$ & 7,000 & 7.4 \\
\hline & $6-9-76$ & $N F$ & 280 & 6.1 & 7 & $6-4-75$ & $-\underline{a} /$ & 3,750 & 7.1 \\
\hline & $7-27-76$ & $\mathrm{NF}$ & 280 & 6.2 & 8 & $6-4-75$ & - & 7,000 & 7.9 \\
\hline & $8-31-77$ & $\mathrm{NF}$ & 83 & 6.5 & 9 & $5-21-75$ & $\mathrm{NF}$ & 340 & 6.6 \\
\hline & $11-10-77$ & $\mathrm{NF}$ & 125 & 6.5 & & $7-14-76$ & $\mathrm{NF}$ & 390 & 6.6 \\
\hline \multirow[t]{6}{*}{2} & $9-3-75$ & - & 1,500 & 4.8 & & $11-10-77$ & $\mathrm{NF}$ & 350 & 6.6 \\
\hline & $4-27-76$ & 76 & 2,000 & 5.0 & 10 & $6-4-75$ & - & 2,100 & 7.7 \\
\hline & $6-9-76$ & 89 & 1,900 & 4.9 & 11 & $6-18-75$ & NF & 65 & 5.6 \\
\hline & $5-18-77$ & 63 & 2,800 & 4.0 & 12 & $6-18-75$ & NF & 245 & 4.9 \\
\hline & $12-5-77$ & 215 & 1,600 & 4.9 & 13 & $6-18-75$ & $\mathrm{NF}$ & 160 & 5.8 \\
\hline & $12-21-77$ & 125 & 1,875 & 4.7 & 14 & $6-18-75$ & $\mathrm{NF}$ & 210 & 6.6 \\
\hline \multirow[t]{3}{*}{3} & $11-21-77$ & 23 & 1,820 & 5.8 & 15 & $6-18-75$ & $\mathrm{NF}$ & 305 & 6.0 \\
\hline & $12-21-77$ & 34 & 1,790 & 5.7 & 16 & $10-6-77$ & 90 & 975 & 6.9 \\
\hline & $1-24-78$ & 53 & - & - & & $11-17-77$ & 150 & 950 & 7.1 \\
\hline 4 & $3-10-76$ & 3 & 900 & 5.1 & 17 & $3-10-76$ & - & 1,200 & 6.6 \\
\hline \multirow[t]{7}{*}{5} & $8-12-75$ & NF & 260 & 6.9 & & $7-14-76$ & - & 1,050 & 6.3 \\
\hline & $6-9-76$ & NF & 350 & 4.5 & 18 & $3-10-76$ & - & 1,100 & 6.6 \\
\hline & $4-27-77$ & $\mathrm{NF}$ & 320 & 5.0 & & $7-14-76$ & - & 640 & 6.9 \\
\hline & $9-20-77$ & NF & 925 & 6.4 & 19 & $7-9-76$ & NF & 150 & 6.5 \\
\hline & $11-10-77$ & $\mathrm{NF}$ & 310 & 6.3 & 20 & - & $\mathrm{NF}$ & 410 & 6.5 \\
\hline & $3-6-78$ & NF & 510 & 6.4 & $20 \mathrm{~A}$ & $3-31-78$ & 750 b/ & - & 7.3 \\
\hline & $3-6-78$ & $\mathrm{NF}$ & 810 & 6.3 & & & & & \\
\hline
\end{tabular}

a/ Total pumpage from sites 6 and 7 during mining was estimated at $800,000 \mathrm{gal} / \mathrm{d}$. Mine presently being filled with sludge.

b/ Mine pumped 15-20 minutes daily.

$\overline{\mathrm{N}} \mathrm{F}$ No flow. 
Table 4.--Field measurements of mine discharge, specific conductance and pH, Johnson County

\begin{tabular}{|c|c|c|c|c|c|c|c|c|c|}
\hline Site & Date & $\begin{array}{r}\text { Discharge } \\
(\mathrm{gal} / \mathrm{min})\end{array}$ & $\begin{array}{l}\text { Specific conductance } \\
\text { (micromhos per cm } \\
\text { at } 25^{\circ} \mathrm{C} \text { ) }\end{array}$ & (units) & Site & Date & $\begin{array}{l}\text { Discharge } \\
\text { (ga1/min) }\end{array}$ & $\begin{array}{l}\text { Specific conductance } \\
\text { (micromhos per cm } \\
\text { at } 25^{\circ} \mathrm{C} \text { ) }\end{array}$ & $\begin{array}{c}\mathrm{pH} \\
\text { (units) }\end{array}$ \\
\hline \multirow[t]{16}{*}{21} & $3-10-76$ & 45 & 615 & 7.5 & 23 & $4-9-76$ & 60 & 685 & 3.8 \\
\hline & $4-27-76$ & 73 & 800 & 7.0 & & $4-27-76$ & 44 & 800 & 5.0 \\
\hline & $6-10-76$ & 40 & 820 & 7.4 & & $6-10-76$ & 14 & 925 & 4.0 \\
\hline & $8-11-76$ & 27 & 800 & 7.2 & & $8-11-76$ & 11 & 930 & 4.0 \\
\hline & $8-31-76$ & 24 & 900 & 7.1 & & $8-31-76$ & 2 & 1,100 & 4.2 \\
\hline & $10-26-76$ & 40 & 760 & 7.5 & & $10-26-76$ & 15 & 750 & 4.0 \\
\hline & $11-10-77$ & 40 & 805 & 6.3 & & $11-16-77$ & $\mathrm{NF}$ & 965 & 4.0 \\
\hline & $12-5-77$ & 64 & 805 & 6.2 & 24 & $4-28-76$ & 3 & 860 & 4.4 \\
\hline & $12-7-77$ & 64 & 750 & 6.4 & & $4-9-76$ & 10 & 770 & 3.7 \\
\hline & $12-20-77$ & 53 & 805 & 6.4 & & $11-16-77$ & 16 & 1,010 & 4.0 \\
\hline & $1-23-78$ & 82 & 740 & 6.6 & & $12-8-77$ & 33 & 965. & 3.8 \\
\hline & $1-25-78$ & 180 & 715 & 6.5 & & $12-20-77$ & 18 & 1,050 & 3.8 \\
\hline & $1-25-78$ & 200 & 760 & 6.5 & & $1-25-76$ & 60 & - & - \\
\hline & $1-26-78$ & 1,700 & 535 & 6.3 & 25 & $4-9-76$ & 10 & 360 & 4.6 \\
\hline & $1-27-78$ & 600 & 495 & 6.3 & 26 & $4-28-76$ & 6 & 590 & 5.0 \\
\hline & $1-27-78$ & 430 & 520 & 6.3 & & $6-10-76$ & 4 & 650 & 4.8 \\
\hline \multirow[t]{10}{*}{22} & $4-13-76$ & 25 & 560 & 5.0 & & $8-31-76$ & 2 & 850 & 5.2 \\
\hline & $4-28-76$ & 65 & 660 & 5.0 & & $11-10-77$ & 3 & 740 & 5.2 \\
\hline & $6-30-76$ & 50 & 600 & 5.7 & & $12-20-77$ & 4 & 750 & 4.8 \\
\hline & $8-31-76$ & 29 & 850 & 5.2 & 27 & $4-9-76$ & 12 & 1,200 & 4.3 \\
\hline & $10-26-76$ & 31 & 845 & 4.5 & & $4-27-76$ & 18 & 1,700 & 5.0 \\
\hline & $11-10-77$ & 23 & 910 & 5.5 & & $8-11-76$ & 17 & 1,550 & 4.5 \\
\hline & $12-5-77$ & 37 & 930 & 5.6 & & $11-16-77$ & 20 & 1,550 & 6.1 \\
\hline & $12-7-77$ & 36 & 930 & 5.5 & & $12-20-77$ & 29 & 1,600 & 6.1 \\
\hline & $12-20-77$ & 47 & 910 & 5.5 & & $1-5-78$ & 27 & 1,600 & 6.0 \\
\hline & $1-23-78$ & 51 & 880 & 5.6 & & & & & \\
\hline
\end{tabular}

NF No flow. 
Table 4.--Field measurments of mine discharge, specific conductance and $\mathrm{pH}$, Johnson County--Continued

\begin{tabular}{|c|c|c|c|c|c|c|c|c|c|}
\hline Site & Date & $\begin{array}{l}\text { Discharge } \\
\text { (gal/mIn) }\end{array}$ & $\begin{array}{l}\text { Specific conductance } \\
(\text { micromhos per cm } \\
\text { at } 25^{\circ} \mathrm{C} \text { ) }\end{array}$ & $\begin{array}{c}\mathrm{pH} \\
\text { (units) }\end{array}$ & Site & Date & $\begin{array}{l}\text { Discharge } \\
\text { (gal/min) }\end{array}$ & $\begin{array}{l}\text { Specific conductance } \\
(\text { micromhos per cm } \\
\text { at } 25^{\circ} \mathrm{C} \text { ) }\end{array}$ & $\begin{array}{c}\mathrm{pH} \\
\text { (units) }\end{array}$ \\
\hline \multirow[t]{4}{*}{28} & $4-9-76$ & 9 & 560 & 3.9 & 43 & $3-11-76$ & 3 & 200 & 5.3 \\
\hline & $6-10-76$ & - & 825 & 4.0 & 44 & $3-8-78$ & $\mathrm{NF}$ & 230 & 5.7 \\
\hline & $11-11-77$ & 10 & 1,000 & 6.9 & 45 & $3-8-78$ & $\mathrm{NF}$ & 700 & 7.1 \\
\hline & $12-20-77$ & 12 & 950 & 6.9 & 47 & $9-1-77$ & $\mathrm{NF}$ & 540 & 6.7 \\
\hline 29 & $4-9-76$ & 9 & 1,000 & 5.0 & & $11-17-77$ & $\mathrm{NF}$ & 480 & 6.8 \\
\hline 30 & $11-11-77$ & 3 & 890 & 4.6 & 49 & $4-7-76$ & 10 & 340 & 6.0 \\
\hline 31 & $11-11-77$ & 2 & 1,420 & 3.2 & 50 & $4-8-76$ & $\mathrm{NF}$ & 170 & 5.5 \\
\hline 32 & $4-13-76$ & 1 & 510 & 4.7 & 51 & $4-9-76$ & $<1$ & 360 & 3.7 \\
\hline 33 & $12-8-77$ & NF & 540 & 6.5 & 52 & $4-9-76$ & 3 & 790 & 4.0 \\
\hline 34 & $3-11-76$ & 3 & 875 & 5.1 & & $6-30-76$ & $\mathrm{NF}$ & 1,650 & 3.5 \\
\hline 35 & $12-8-77$ & 6 & 810 & 4.8 & & $11-9-77$ & 3 & 1,490 & 3.6 \\
\hline 36 & $12-8-77$ & 1 & 480 & 4.2 & 53 & $4-13-76$ & 2 & 230 & 4.0 \\
\hline 37 & $12-8-77$ & 2 & 1,000 & 4.8 & 54 & $3-17-76$ & $\mathrm{NF}$ & 530 & 3.5 \\
\hline 38 & $12-8-77$ & 5 & 520 & 4.5 & & $6-29-76$ & $N F$ & 1,500 & 3.1 \\
\hline 39 & $4-5-78$ & 35 & 980 & 5.9 & & $11-21-77$ & $N F$ & 495 & 3.6 \\
\hline 40 & $12-8-77$ & 4 & 450 & 6.7 & 55 & $3-11-76$ & 8 & 5,000 & 5.1 \\
\hline \multirow[t]{4}{*}{41} & $12-8-77$ & 35 & 1,180 & 4.0 & 56 & $3-11-76$ & 2 & 340 & 5.1 \\
\hline & $12-21-77$ & 19 & 1,385 & 3.8 & 57 & $3-11-76$ & 5 & 255 & 4.0 \\
\hline & $1-5-78$ & 17 & 1,340 & 3.9 & 58 & $6-29-76$ & - & 505 & 6.5 \\
\hline & $1-24-78$ & 40 & - & - & & $9-21-77$ & 10 & 470 & 6.5 \\
\hline \multirow[t]{5}{*}{42} & $3-11-76$ & 20 & 750 & 3.7 & & $11-9-77$ & 5 & 450 & 6.4 \\
\hline & $4-27-76$ & 1 & 850 & 4.8 & & $12-19-77$ & 20 & 395 & 6.2 \\
\hline & $9-29-76$ & 10 & 700 & 3.7 & 59 & $6-29-76$ & 10 & 570 & 7.2 \\
\hline & $11-14-77$ & 18 & 770 & 3.8 & & $11-9-77$ & 6 & 740 & 4.6 \\
\hline & $12-19-77$ & 15 & 740 & 4.0 & & $12-19-77$ & 9 & 655 & 6.9 \\
\hline
\end{tabular}

NF No flow. 
Table 4.--Field measurements of mine discharge, specific conductance and $\mathrm{pH}$, Johnson County--Continued

\begin{tabular}{|c|c|c|c|c|c|c|c|c|c|}
\hline Site & Date & $\begin{array}{l}\text { Discharge } \\
\text { (ga1/min) }\end{array}$ & $\begin{array}{l}\text { Specific conductance } \\
\text { (micromhos per cm } \\
\text { at } 25^{\circ} \mathrm{C} \text { ) }\end{array}$ & $\begin{array}{c}\mathrm{pH} \\
\text { (units) }\end{array}$ & Site & Date & $\begin{array}{l}\text { Discharge } \\
\text { (gal/min) }\end{array}$ & $\begin{array}{l}\text { Specific conductance } \\
\text { (micromhos per cm } \\
\text { at } 25^{\circ} \mathrm{C} \text { ) }\end{array}$ & $\begin{array}{c}\mathrm{pH} \\
\text { (units) }\end{array}$ \\
\hline \multirow[t]{3}{*}{60} & $3-17-76$ & $\mathrm{NF}$ & 310 & 5.5 & 71 & $4-1-76$ & 1 & 260 & 5.1 \\
\hline & $6-29-76$ & $\mathrm{NF}$ & 318 & 5.9 & 72 & $4-1-76$ & 3 & 360 & 6.1 \\
\hline & $11-9-77$ & NF & 330 & 5.5 & 73 & $8-12-76$ & $\mathrm{NF}$ & 330 & 7.0 \\
\hline 61 & $3-17-76$ & 4 & 850 & 6.3 & & $11-11-77$ & $\mathrm{NF}$ & 270 & 6.2 \\
\hline 62 & $3-17-76$ & 4 & 940 & 5.2 & & $12-21-77$ & $\mathrm{NF}$ & 230 & 6.7 \\
\hline \multirow[t]{3}{*}{63} & $3-30-76$ & 60 & 900 & 5.0 & 74 & $6-8-76$ & - & 2,180 & 4.1 \\
\hline & $4-27-76$ & 3 & 1,100 & 4.0 & & $5-27-76$ & - & 1,850 & 7.2 \\
\hline & $6-7-77$ & NF & - & - & 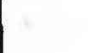 & $9-1-76$ & 750 & - & - \\
\hline 64 & $3-31-76$ & $\mathrm{NF}$ & 2,900 & 3.1 & & $11-11-77$ & - & 1,920 & 6.9 \\
\hline \multirow[t]{2}{*}{65} & $4-7-76$ & $<1$ & 340 & 5.4 & & $12-21-77$ & - & 1,940 & 7.2 \\
\hline & $12-7-77$ & $<1$ & 420 & 5.2 & & $1-4-78$ & 1,200 & - & - \\
\hline \multirow[t]{4}{*}{66} & $4-7-76$ & 6 & 520 & 4.0 & 75 & $5-27-76$ & $\mathrm{NF}$ & 710 & 6.7 \\
\hline & $7-15-76$ & 8 & 760 & 4.2 & & $7-15-76$ & $\mathrm{NF}$ & 900 & 8.0 \\
\hline & $11-11-77$ & - & 785 & 4.3 & & $11-17-77$ & $\mathrm{NF}$ & 530 & 6.7 \\
\hline & $12-21-77$ & 8 & 730 & 4.1 & 76 & $5-27-76$ & $\mathrm{NF}$ & 270 & 7.2 \\
\hline \multirow[t]{2}{*}{67} & $4-7-76$ & $\mathrm{NF}$ & 800 & 3.3 & & $8-11-76$ & $\mathrm{NF}$ & 400 & 6.2 \\
\hline & $12-7-77$ & 2 & 800 & 3.6 & & $11-11-77$ & $\mathrm{NF}$ & 380 & 7.2 \\
\hline \multirow[t]{2}{*}{68} & $4-7-76$ & 1 & 440 & 4.0 & 77 & $3-10-76$ & 10 & 660 & 6.3 \\
\hline & $12-7-77$ & NF & 280 & 3.8 & 78 & $11-11-77$ & $-\underline{a} /$ & 2,100 & 6.9 \\
\hline 69 & $12-7-77$ & 5 & 790 & 3.9 & & & & & \\
\hline 70 & $4-8-76$ & 6 & 1,400 & 3.4 & & & & & \\
\hline & $4-8-76$ & 10 & 1,200 & 3.8 & & & & & \\
\hline
\end{tabular}

a/ Water is pumped from airshaft to supply 11 houses.

$\overline{N F}$ No flow. 


\section{Mines Above Drainage}

Mines are classified in this report as "above drainage" if the mine galleries are at higher elevations than the nearest perennial stream. The quantity of water available from above-drainage mines can best be estimated by measuring the range of discharge from each mine for a period of at least one year. The flow from the mine represents the maximum quantity of water avai1able unless additional water is available from storage within the mine. Because mine-discharge changes seasonally, the amount of water available for use is highly variable. A water supply from above-drainage mines can be made more dependable by sealing the mine openings allowing wet-weather flows to be impounded within the mine for use during low-flow periods.

The seasonal variability of flow from above-drainage mines is illustrated in figure 5. Entrances to two mines, North East Coa1 Company Mines No. 1 and No. 3 (sites 21 and 22), were equipped with V-notch weirs and water-leve1 recorders to monitor seasonal variability of mine-water discharge. Other entrances discharge water from these mines but were not monitored on a continuous basis. The 1-year period of record from May 15, 1977, through May 15, 1978, shows that discharge from both mine entries was variable, although discharge from the portal of the North East Coal Company Mine No. 3 at site 22 was less variable than discharge from the Mine No. 1 portal at site 21 . Discharge from site 21 was in fact the most variable of any mine entry measured in Johnson or Martin County during this investigation. Discharge from this mine entry responded rapidly to precipitation and ranged from 23 to 1,700 gal/min during the period of record. Discharge from the larger North East Coal Company No. 4 Mine at site 22 was less but considerably more uniform, ranging between 23 to $80 \mathrm{gal} / \mathrm{min}$. The difference in response of the two sites can be explained in part by the character of the openings from which the water discharges. The mine entry at site 22 has collapsed, thereby impounding water behind the fallen debris. Water bubbles up as a spring in front of the dam. However, the portal at Number 1 Mine (site 21) is open and water flows freely from it.

The hydrograph in figure 5 shows that base flow from both mines begins to increase in early November. With the exception of the series of storms from August 11-14, the intense summer rains of 1977 did not significantly affect the discharge of either mine. Apparently, the precipitation during August exceeded evapotranspiration demands and recharge to the mines was sufficient to increase discharge. The hydrograph for each mine shows peaks in midJanuary and March with lesser peaks in late April of 1978. These peaks show the effect of relatively heavy rainfall preceded by periods of average precipitation in winter months while vegetation was dormant.

The difference in mine discharge during summer and winter months can be quantified by analyzing discharge as a percentage of precipitation falling on the mined-out area. During the recharge months November 1977 to May 1978 , precipitation totalled 601 acre-feet on the 275 acre surface area of the North East Coal Company Mine No. 1. Mine discharge measured from the entry at site 21 was 168 acre-feet for the same period. This site is the only 

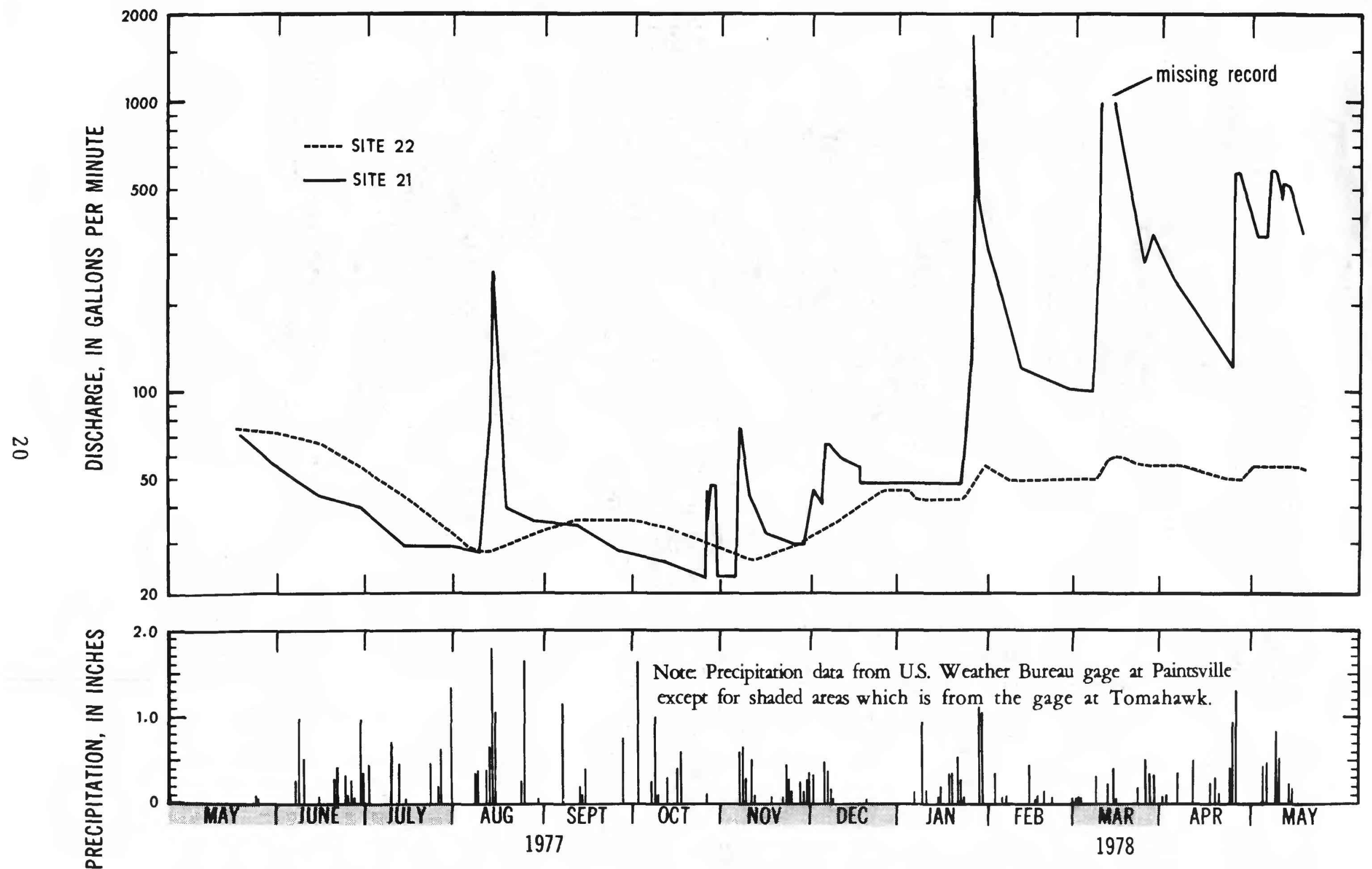

Figure 5. - Hydrograph of discharge from mine entries at sites 21 and 22 and precipitation for the period of record May 15, 1977 through May 15, 1978. 
outlet for water from the mine other than the small flow measured at site 74 . If only discharge from site 21 is considered, discharge from the North East Coal Company Mine No. 1 was 28 percent of incident precipitation during the recharge season. During the period June-September, 1977, precipitation totaled 517 acre-feet but discharge from the mine at site 22 was only 24 acre-feet which was less than 5 percent of the total precipitation during the period.

The potential of a coal mine to provide large quantities of water throughout the year is dependent to a great extent upon the size of the mine. Obviously a large mine should be able to supply more water than a small mine. Since many of the large mines discharge water through several openings, the range of discharge from an individual mine was estimated by summing the flows for all points of discharge from that mine (table 5). The estimates are subject to potentially large error because the mine-discharge was sampled with varying frequencies and at different times of the year.

The quantitative relation between the amount of water discharging from a mine and the size of mined area is illustrated on figure 6. This graph shows the relation between the total discharge from a particular mine (table 5) and the mined area as calculated from mine maps on file at the Institute for Mining and Mineral Research, Lexington, Kentucky. The highest and lowest totaled discharges from all openings from a particular mine were plotted to show a range of total discharge from each mine (fig. 6). The figure illustrates the strong correlation between mine size and discharge. This relation was expected becausé large mined areas have large recharge areas. Although this relation was developed only for above-drainage mines, a similar relation probably exists between mine size and recharge rates for mines below drainage. It is the large mines therefore, both above and below drainage, which have the greatest potential as sources for water supply.

The total, annual discharge from selected mines was calculated as a percentage of the total amount of precipitation falling on the surface area of the mine during the year (table 6). The annual discharge of all mines analyzed varied from 3 to 10 percent of annual, incident precipitation with the exception of North East Coal Company Mine No. 1 and Stambaugh Coal Company Mines No. 1 and 2. The variation in discharge as a percent of precipitation is probably controlled by many factors including: duration and intensity of precipitation, depth to mining horizon, degree of fracturing, and degree of hydrologic connection within the mine. If discharge is 3 to 10 percent of incident precipitation for most mines, then the expected range of average discharge from mines of various sizes is shown on figure 7 based on an annual precipitation of 43.6 inches.

Based upon discharge rates measured during the study period, the above-drainage mines with the best water-supply potential in the study area are listed in table 7. The post-mining volume of each mine is listed as an estimate of the maximum potential water-storage capacity. It is likely that only a small percentage of the post-mining volume contains water in abovedrainage mines because water is generally free to drain from the mine. Thus 
Table 5.--Maximum, minimum, and mean mine discharges calculated as sum of discharge from all entries for selected above-drainage mines

\begin{tabular}{|c|c|c|c|c|c|}
\hline Mine name & $\begin{array}{l}\text { Site number } \\
\text { of mine } \\
\text { entry where } \\
\text { water discharges }\end{array}$ & $\begin{array}{l}\text { Minimum } \\
\text { discharge } \\
\text { measured } \\
\text { at site } \\
\text { (gal/min) }\end{array}$ & $\begin{array}{l}\text { Maximum } \\
\text { discharge } \\
\text { measured } \\
\text { at site } \\
\text { (gal/min) }\end{array}$ & $\begin{array}{c}\text { Mean } \\
\text { discharge } \\
\text { (gal/min) }\end{array}$ & $\begin{array}{l}\text { Number of } \\
\text { discharge } \\
\text { measurements }\end{array}$ \\
\hline
\end{tabular}

Stambaugh Coal Co. Mines No. 1 and No. 2 .

William's Mining Co. No. 1

$\mathrm{M} \& \mathrm{P}$ Coal Co.

No. 1

Hagar Hill Mining Co. No. 1 and No. 2

Tutor Key Coal Co. No. 1

North East Coal Co. No. 1

North East Coal Co. No. 5

North East Coal Co. No. 2

North East Coal Co. No. 3 and No. 4

Buck Creek Coal Co., Himmler and Earlston Mines and Collins Creek Coal Co. Sluss Mine (connected)

Consolidated Coal Co. No. 151-155

\begin{tabular}{crrrr}
42 & 1 & 20 & 13 & 5 \\
43 & 3 & 3 & 3 & 1 \\
\hline Total of all sites & 4 & 23 & 16 & 6
\end{tabular}

\begin{tabular}{cllll}
66 & 6 & 8 & 7 & 3 \\
\hline Total of all sites & 6 & 8 & 7 & 3
\end{tabular}

\begin{tabular}{ccccc}
58 & 5 & 20 & 12 & 3 \\
\hline Total of all sites & 5 & 20 & 12 & 3 \\
59 & 6 & 10 & 8 & 3 \\
60 & 0 & 0 & 0 & 3 \\
\hline Total of al1 sites & 6 & 10 & 8 & 6
\end{tabular}

\begin{tabular}{cllll}
41 & 17 & 40 & 28 & 4 \\
\hline Total of al1 sites & 17 & 40 & 28 & 4
\end{tabular}

\begin{tabular}{crrrr}
21 & 25 & 1700 & 120 & Continuous gage \\
77 & 10 & 10 & 10 & 1 \\
\hline Total of all sites & 35 & 1710 & 130 & -
\end{tabular}

\begin{tabular}{crrrr}
34 & 3 & 3 & 3 & 1 \\
35 & 6 & 6 & 6 & 1 \\
36 & 1 & 1 & 1 & 1 \\
37 & 2 & 2 & 2 & 1 \\
38 & 5 & 5 & 5 & 1 \\
39 & 35 & 35 & 35 & 1 \\
\hline Total of all sites & 52 & 52 & 52 & 6
\end{tabular}

\begin{tabular}{crrrr}
26 & 2 & 6 & 4 & 5 \\
27 & 12 & 29 & 21 & 6 \\
28 & 9 & 12 & 10 & 3 \\
29 & 9 & 9 & 9 & 1 \\
30 & 3 & 3 & 3 & 1 \\
31 & 2 & 2 & 2 & 1 \\
\hline Total of all sites & 37 & 61 & 49 & 17
\end{tabular}

\begin{tabular}{crrrr}
22 & 23 & 74 & 45 & Continuous gage \\
23 & 0 & 60 & 21 & 7 \\
24 & 3 & 60 & 23 & 6 \\
25 & 10 & 10 & 10 & 1 \\
\hline Total of all sites & 36 & 195 & 99 & -
\end{tabular}

\begin{tabular}{crrrr}
2 & 76 & 215 & 108 & 4 \\
3 & 23 & 54 & 37 & 3 \\
4 & 3 & 3 & 3 & 1 \\
\hline Total of all sites & 102 & 272 & 148 & 8 \\
74 & & & & \\
\hline Total of all sites & 750 & 1200 & 975 & 2
\end{tabular}




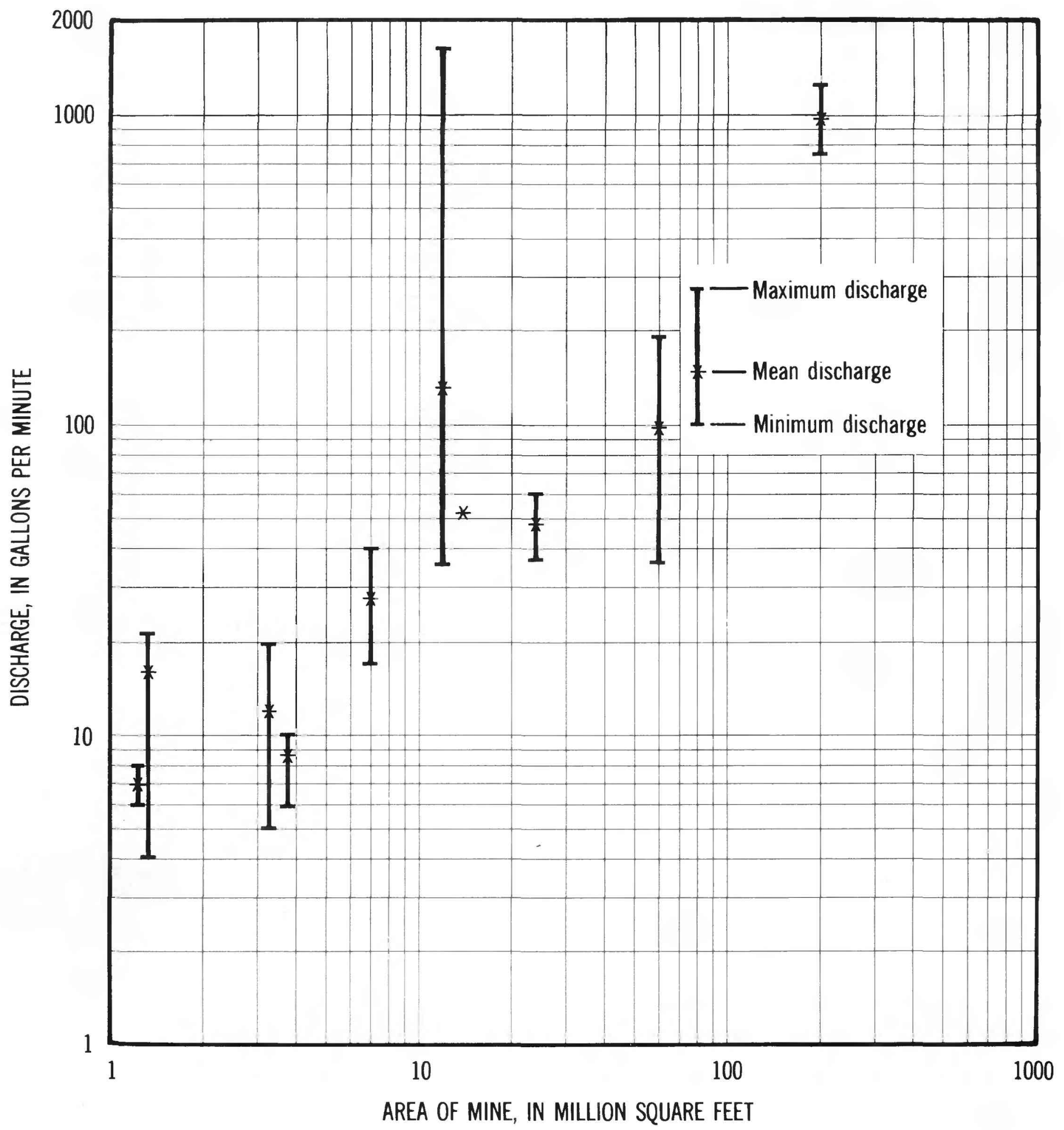

Figure 6. - Relation of mine size to total discharge measured from above-drainage mines. 
Table 6.--Calculation of mine discharge as percent of precipitation on land surface above mine.

\begin{tabular}{|c|c|c|c|c|c|c|}
\hline Mine name & $\begin{array}{r}\text { Averag } \\
\text { dischai } \\
\text { a11 } \\
\text { (gal/min) } \\
\end{array}$ & $\begin{array}{l}\text { ge mine } \\
\text { rge from } \\
\text { entries } \\
(\mathrm{M} \mathrm{ft} / \mathrm{yr}) \\
\end{array}$ & $\begin{array}{c}\text { Areal } \\
\text { extent } \\
\text { of } \\
\text { mine } \\
\left(\mathrm{M} \mathrm{ft}^{2}\right) \\
\end{array}$ & $\begin{array}{c}\text { Mean, annual } \\
\text { precipita- } \\
\text { tion at } \\
\text { Paintsville } \\
1975-77 \\
(\mathrm{ft} / \mathrm{yr}) \\
\end{array}$ & $\begin{array}{l}\text { Total inci- } \\
\text { dent pre- } \\
\text { cipitation } \\
\text { on mine per } \\
\text { year } \\
\left(\mathrm{M} \mathrm{ft}^{3} / \mathrm{yr}\right) \\
\end{array}$ & $\begin{array}{c}\text { Mine } \\
\text { discharge } \\
\text { as percent } \\
\text { of incident } \\
\text { precipitation }\end{array}$ \\
\hline $\begin{array}{l}\text { Stambaugh Coal Co. } \\
\text { Mines No. } 1 \text { and No. } 2\end{array}$ & 16 & 1.12 & 1.3 & 3.66 & 4.8 & 23 \\
\hline $\begin{array}{l}\text { William's Mining Co. } \\
\text { No. } 1\end{array}$ & 7 & .49 & 1.3 & 3.66 & 4.8 & 10 \\
\hline $\begin{array}{l}\text { M \& P Coal Co. } \\
\text { No. } 1\end{array}$ & 12 & .84 & 3.3 & 3.66 & 12.1 & 7 \\
\hline $\begin{array}{l}\text { Hagar Hill Mining Co. } \\
\text { No. } 1 \text { and No. } 2\end{array}$ & 8 & .56 & 3.8 & 3.66 & 13.9 & 4 \\
\hline $\begin{array}{l}\text { Tutor Key Coal Co. } \\
\text { No. } 1\end{array}$ & 28 & 1.97 & 6.8 & 3.66 & 24.9 & 8 \\
\hline $\begin{array}{l}\text { North East Coal Co. } \\
\text { No. } 1\end{array}$ & 130 & 9.13 & 12 & 3.66 & 43.9 & 21 \\
\hline $\begin{array}{l}\text { North East Coal Co. } \\
\text { No. } 5\end{array}$ & 52 & 3.65 & 13.6 & 3.66 & 49.8 & 7 \\
\hline $\begin{array}{l}\text { North East Coal Co. } \\
\text { No. } 2\end{array}$ & 49 & 3.44 & 23.6 & 3.66 & 86.4 & 4 \\
\hline $\begin{array}{l}\text { North East Coal Co. } \\
\text { No. } 3 \text { and No. } 4\end{array}$ & 99 & 6.96 & 58.4 & 3.66 & 213 & 3 \\
\hline $\begin{array}{l}\text { Buck Creek Coal Co., } \\
\text { Himmler and Earlston } \\
\text { Mines; Collins Creek } \\
\text { Coal Co., Sluss Mine }\end{array}$ & 148 & 10.4 & 78 & 3.66 & 285 & 4 \\
\hline $\begin{array}{l}\text { Consolidated Coal Co. } \\
\text { No. 151-155 }\end{array}$ & 975 & 68.5 & 204 & 3.66 & 747 & 9 \\
\hline
\end{tabular}




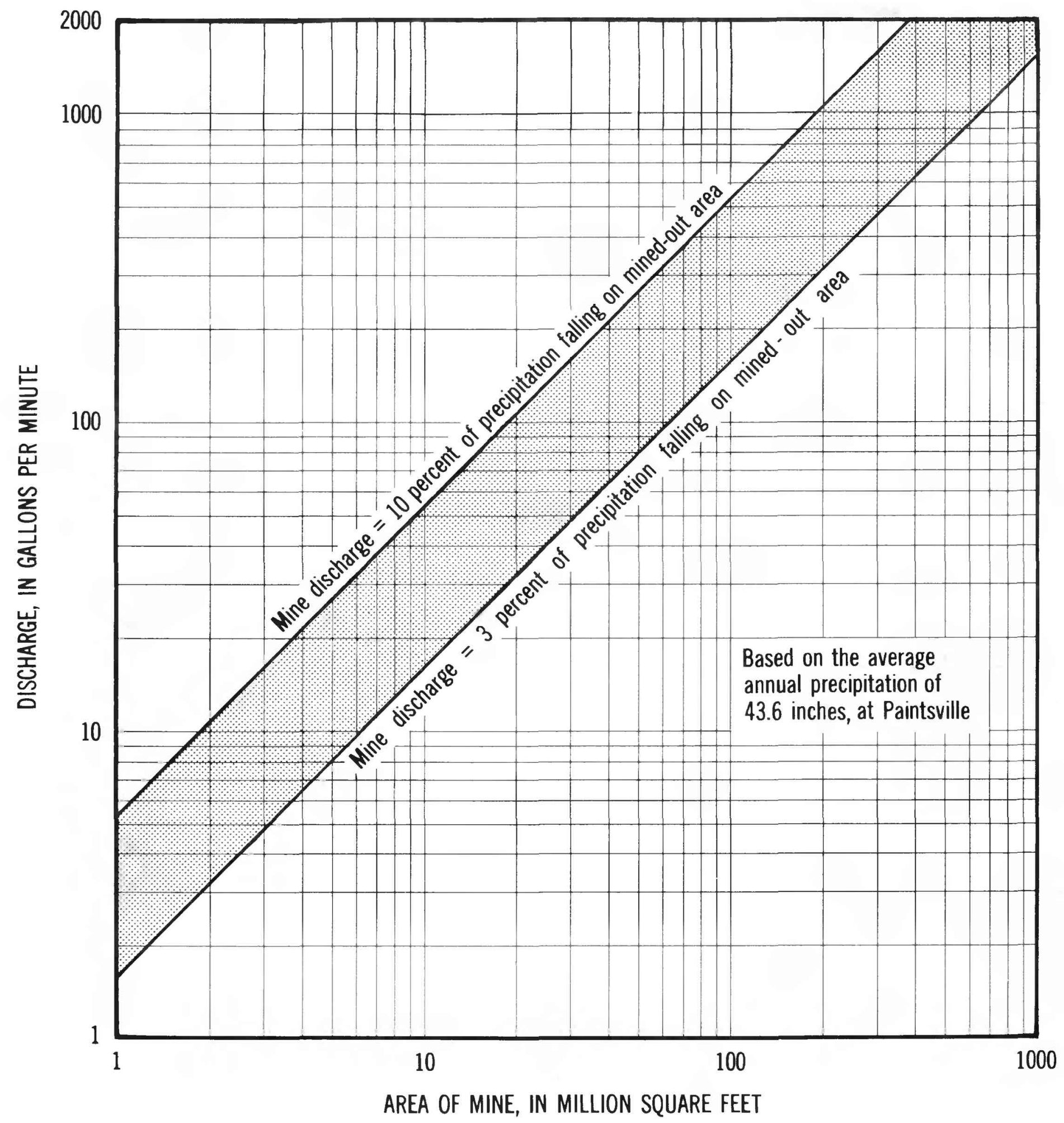

Figure 7. - Range of average discharge (totaled from all discharge points) for mines above drainage. 
Table 7.--Above-drainage mines with best water-supply potential

\begin{tabular}{|c|c|c|c|c|c|}
\hline $\begin{array}{l}\text { Site } \\
\text { number of } \\
\text { mine opening } \\
\end{array}$ & Name & $\begin{array}{l}\text { Estimated } \\
\text { storage } \\
\text { volume } \\
\left(\mathrm{M} \mathrm{ft}{ }^{3}\right) \\
\end{array}$ & $\begin{array}{l}\text { Range of dis- } \\
\text { charge from } \\
\text { single opening } \\
\text { (gal/min) } \\
\end{array}$ & $\begin{array}{c}\text { Coal seam } \\
\text { mined }\end{array}$ & Remarks \\
\hline 2 & $\begin{array}{l}\text { Buck Creek Coal Co., } \\
\text { Coleman Mine }\end{array}$ & 195 & $63-215$ & Alma & $\begin{array}{l}\text { Reportedly connected with } \\
\text { Himmler, Earlston and } \\
\text { Sluss mines. Flows } \\
\text { freely from main portal. }\end{array}$ \\
\hline 3 & $\begin{array}{l}\text { Buck Creek Coal Co., } \\
\text { Coleman Mine }\end{array}$ & 195 & $17-40$ & Alma & $\begin{array}{l}\text { Reportedly connected with } \\
\text { larger Himmler, Earlston } \\
\text { and Sluss mines. Water } \\
\text { discharges as spring, } \\
\text { not from a mine opening. }\end{array}$ \\
\hline 6 & $\begin{array}{l}\text { Martin County Coal } \\
\text { Co., Coalburg Mine } \\
\text { No.'1 }\end{array}$ & 22 & $90-150$ & $\begin{array}{l}\text { Peach } \\
\text { Orchard }\end{array}$ & $\begin{array}{l}\text { Water pumped from working } \\
\text { mine. }\end{array}$ \\
\hline 21 & $\begin{array}{l}\text { North East Coal Co., } \\
\text { Mine No. } 1\end{array}$ & 30 & $24-1,700$ & Van Lear & $\begin{array}{l}\text { Water discharges freely } \\
\text { from open portal. }\end{array}$ \\
\hline 22 & $\begin{array}{l}\text { North East Coal Co., } \\
\text { Mine No. } 3\end{array}$ & 146 & $23-65$ & Van Lear & $\begin{array}{l}\text { N.E.C.C. Mines } 3 \text { and } 4 \text { re- } \\
\text { portedly connected. Dis- } \\
\text { charges through collapsed } \\
\text { adit. }\end{array}$ \\
\hline 24 & $\begin{array}{l}\text { North East Coal Co., } \\
\text { Mine No. } 4\end{array}$ & 146 & $16-60$ & Van Lear & $\begin{array}{l}\text { N.E.C.C. Mines } 3 \text { and } 4 \text { re- } \\
\text { portedly connected. Dis- } \\
\text { charges from collapsed } \\
\text { adit. }\end{array}$ \\
\hline 27 & $\begin{array}{l}\text { North East Coal Co., } \\
\text { Mine No. } 2\end{array}$ & 59 & $12-\quad 27$ & Van Lear & $\begin{array}{l}\text { Water discharges through } \\
\text { collapsed adit. Water } \\
\text { used by local resident } \\
\text { for washing. }\end{array}$ \\
\hline 39 & $\begin{array}{l}\text { North East Coal Co., } \\
\text { Mine No. } 5\end{array}$ & 34 & 35 & Van Lear & Reportedly flows all year. \\
\hline 41 & $\begin{array}{l}\text { Tutor Key Coal Co., } \\
\text { Mine No. } 1\end{array}$ & 17 & $17-\quad 40$ & Van Lear & $\begin{array}{l}\text { Flows from pipe driven into } \\
\text { mine. Used by local resi- } \\
\text { dent for nondrinking } \\
\text { purposes. }\end{array}$ \\
\hline 74 & $\begin{array}{l}\text { Consolidation Coa1 } \\
\text { Co., Mines 151-155 }\end{array}$ & 510 & $750-1,200$ & Van Lear & $\begin{array}{l}\text { Reportedly connected with } \\
\text { N.E.C.C. No. } 11 \text { which } \\
\text { provides water of identi- } \\
\text { cal quality for } 11 \text { modern } \\
\text { homes at sites } 76 \text { and } 78 .\end{array}$ \\
\hline
\end{tabular}


the mine volume is an indication of the storage potential which could be utilized if the mines were sealed and allowed to flood.

Al1 the mines listed in table 7 were discharging more than $10 \mathrm{gal} / \mathrm{min}$ from at least one opening when they were field-checked. The range of discharge listed is from a single mine opening identified by site number. Additional entries of the same mine which discharge less than $10 \mathrm{gal} / \mathrm{min}$ are summarized on tables 3 and 4 . The greatest measured discharge was 1,700 $\mathrm{gal} / \mathrm{min}$ from the North East Coal Company No. 1 Mine portal at site 21 . Discharge from the mine at this site usually ranged from 25 to $200 \mathrm{gal} / \mathrm{min}$. Discharge from the Buck Creek Coal Company, Coleman Mine at site 2 in Martin County exceeded $200 \mathrm{gal} / \mathrm{min}$ periodically, but flow was generally less than $100 \mathrm{gal} / \mathrm{min}$. The highest sustained flow was measured at a discharge pipe which reportedly drains the abandoned galleries of the Consolidated Coal Company Mines 151-155 at site 74 in Johnson County. During the study period these mines continuously discharged between 750 and 1,200 gal/min into John's Creek near Van Lear.

\section{Mines Below Drainage}

The volume of water in an abandoned below-drainage mine is usually large because all openings are filled with water. Mines below drainage generally do not discharge water from slope or shaft entries. Thus the recharge characteristics and water-supply potential of these mines can best be estimated by test pumping. In addition, valuable information on the water conditions in the mine during mining can be supplied by coal operators and miners. Based on information from miners and limited test pumping, the below-drainage mines with the best water-supply potentia1 in the study area are listed in table 8 . The site numbers indicate the principal points of access to water in each mine. The post-mining volume of each mine is listed as an estimate of the maximum water-storage capacity. The estimated storage volume is based on mine maps and the assumption that 50 percent of a 5 -foot coal bed was removed from the mine.

A simplified model of the hydrologic system is proposed for belowdrainage mines based on results of two pumping tests. After a rainfall, water infiltrates into an abandoned mine mainly through cracks and fractures in the rocks. The mine and fractures in the rock are saturated to the level of the potentiometric surface. When water is pumped from the mine the pressure in the mine is reduced allowing fractures to dewater vertically into the mine. Horizontal permeability of rocks above the coal mine is probably low so lateral ground-water flow to the mine is restricted. In the summer months when most precipitation is used by plants or evaporated, the mine is recharged only very slowly through vertical fractures. During the late fall and spring months, when vegetation is dormant and precipitation quickly replenishes fractures, mine recharge is relatively rapid. 
Table 8.--Below-drainage mines with best water-supply potential

\begin{tabular}{|c|c|c|c|c|c|}
\hline $\begin{array}{l}\text { Site } \\
\text { number of } \\
\text { mine opening }\end{array}$ & Name & $\begin{array}{l}\text { Estimated } \\
\text { storage } \\
\text { volume } \\
\left.(\mathrm{M} \mathrm{ft})^{3}\right)\end{array}$ & $\begin{array}{l}\text { Estimated } \\
\text { water in } \\
\text { storage } \\
\text { (M gal) }\end{array}$ & $\begin{array}{l}\text { Coal seam } \\
\text { mined }\end{array}$ & Remarks \\
\hline 1 & $\begin{array}{l}\text { Buck Creek Coal Co., } \\
\text { Himmler Mine }\end{array}$ & 195 & 1,462 & Alma & $\begin{array}{l}\text { Connected with Earlston, } \\
\text { Sluss, and Coleman Mines. } \\
\text { Water from Buck Creek } \\
\text { enters mine through roof } \\
\text { collapse. Water pumped } \\
\text { during mining reportedly } \\
\text { very corrosive. }\end{array}$ \\
\hline 5 & $\begin{array}{l}\text { Warfield Mining Co., } \\
\text { No. } 1 \text { Mine }\end{array}$ & 5.7 & 42.7 & Alma & $\begin{array}{l}\text { Mine flooded. During mining, } \\
\text { dewatering reportedly re- } \\
\text { quired pumping at } 5,000- \\
10,000 \text { gal/d. Warfield } \\
\text { pumped } 3,000 \text { gal/d for } \\
\text { emergency water supply. }\end{array}$ \\
\hline 18 & $\begin{array}{l}\text { Martin County Coal, } \\
\text { No. } 1 \text { Stockton }\end{array}$ & 3 & 22.5 & Broas & $\begin{array}{l}\text { Water reportedly pumped } 4 \\
\text { months at } 100,000 \text { gal/d } \\
\text { during mining. Water } \\
\text { levels recovered } 2 \text { days } \\
\text { after pumping stopped. }\end{array}$ \\
\hline 46 & $\begin{array}{l}\text { White Ash Coal Co., } \\
\text { No. } 1 \text { Mine }\end{array}$ & 46 & 345 & Van Lear & $\begin{array}{l}\text { Active mine. Mine is flood. } \\
\text { ing as mining moves updip. } \\
\text { Dewatering reportedly re- } \\
\text { quires pumping } 6 \text { hours per } \\
\text { day from } 3 \text { in. line. }\end{array}$ \\
\hline 47 & $\begin{array}{l}\text { Millers Creek Co-op, } \\
\text { Inc., Whitehouse } \\
\text { Mine }\end{array}$ & 38 & 285 & Van Lear & $\begin{array}{l}\text { Mine flooded. Water pumped } \\
5 \text { hours at } 10 \text { gal/min. No } \\
\text { drawdown. Attempted de- } \\
\text { watering required pumping } \\
1 \text { month with } 8 \text { in. high } \\
\text { pressure pump. Water level } \\
\text { reportedly lowered } 80 \mathrm{ft} \text {. }\end{array}$ \\
\hline 48 & $\begin{array}{l}\text { Royal Collieries, } \\
\text { Offutt Mine }\end{array}$ & 30 & 225 & Van Lear & $\begin{array}{l}\text { Mine flooded. Roof collapse } \\
\text { and fractures in land sur- } \\
\text { face common. }\end{array}$ \\
\hline 58 & $\begin{array}{l}\text { M \& P Coal Co., } \\
\text { No. } 1 \text { Mine }\end{array}$ & 8.3 & 62.3 & Van Lear & $\begin{array}{l}\text { Mine flooded. Airshaft dis- } \\
\text { charges about } 10 \mathrm{gal} / \mathrm{min} \text {. }\end{array}$ \\
\hline
\end{tabular}




\section{Test Pumping}

Two small below-drainage mines were tested with a centrifugal pump capable of pumping $800 \mathrm{gal} / \mathrm{min}$. The pump was positioned at the flooded air shaft of one mine and slope entry of another. The pump could not be lowered into either mine, thus drawdown was limited to the lift capacity of the pump, or about 15 feet below land surface. The water level was observed on staff gages installed at each site. A flow meter on the discharge line measured the discharge rate and recorded the total water pumped from each mine. Water pumped from the mines was discharged into William's Branch during one test and Tug Fork in the other test.

Test pumping illustrates the difficulty of evaluating the dependability of a water supply from a below-drainage mine. Tests conducted in dry summer months may indicate little water-supply potential, but pumping the same mine during the wetter spring months might suggest that greater water supply is possible. The seasonal variation in recharge rates shown by test pumping of below-drainage mines is analogous to the seasonal changes in flow observed from above-drainage mines.

\section{Results of Test Pumping at Site 5}

The abandoned Warfield Mining Company Mine No. 1 (site 5) was testpumped on September 20, 1977, and again on March 6, 1978. The slope entry is about 300 feet west of Tug Fork and is reportedly 56 feet above the Alma (Warfield) coal seam. Coal was removed by conventional room and pillar methods and mine maps indicate that mine pillars were removed in only a few sections. During active mining, the mine was dewatered by pumping at a reported rate of 5,000-10,000 gal/d (gallons per day). After mining ceased in 1963 the mine reportedly flooded overnight following the blasting of a nearby gas we11.

The first pumping test was conducted September 20, 1977, at the slope entry of the mine. During the 6-hour test, the pumping rate was $560 \mathrm{gal} / \mathrm{min}$. Water-level drawdown in the slope is shown on the time-drawdown curves on figure 8. Note that at least 34,000 gallons of water had to be pumped to cause 1 foot of drawdown. Removal of water from storage in the slope entry accounted for only about 1,500 gallons per foot of drawdown. Larger storage was being tapped or water was rapidly recharging the mine as pumping continued. The 77-day recovery data shown on figure 9 tends to discount the possibility of rapid recharge because recovery to the mine from September 20 to November 3 amounted to only 1.16 foot or a rate of $1,150 \mathrm{gal} / \mathrm{d}$. Thus, most of the water pumped was from storage in the main body of the mine and from fractures which were dewatered as pumping progressed.

There is a break in the time-drawdown curve for the time when pumping stopped. When pumping resumed, the slope of the drawdown curve was not as steep as during the first part of the test. This suggests that either the inclined shaft is larger at this level or that a larger section of the mine 


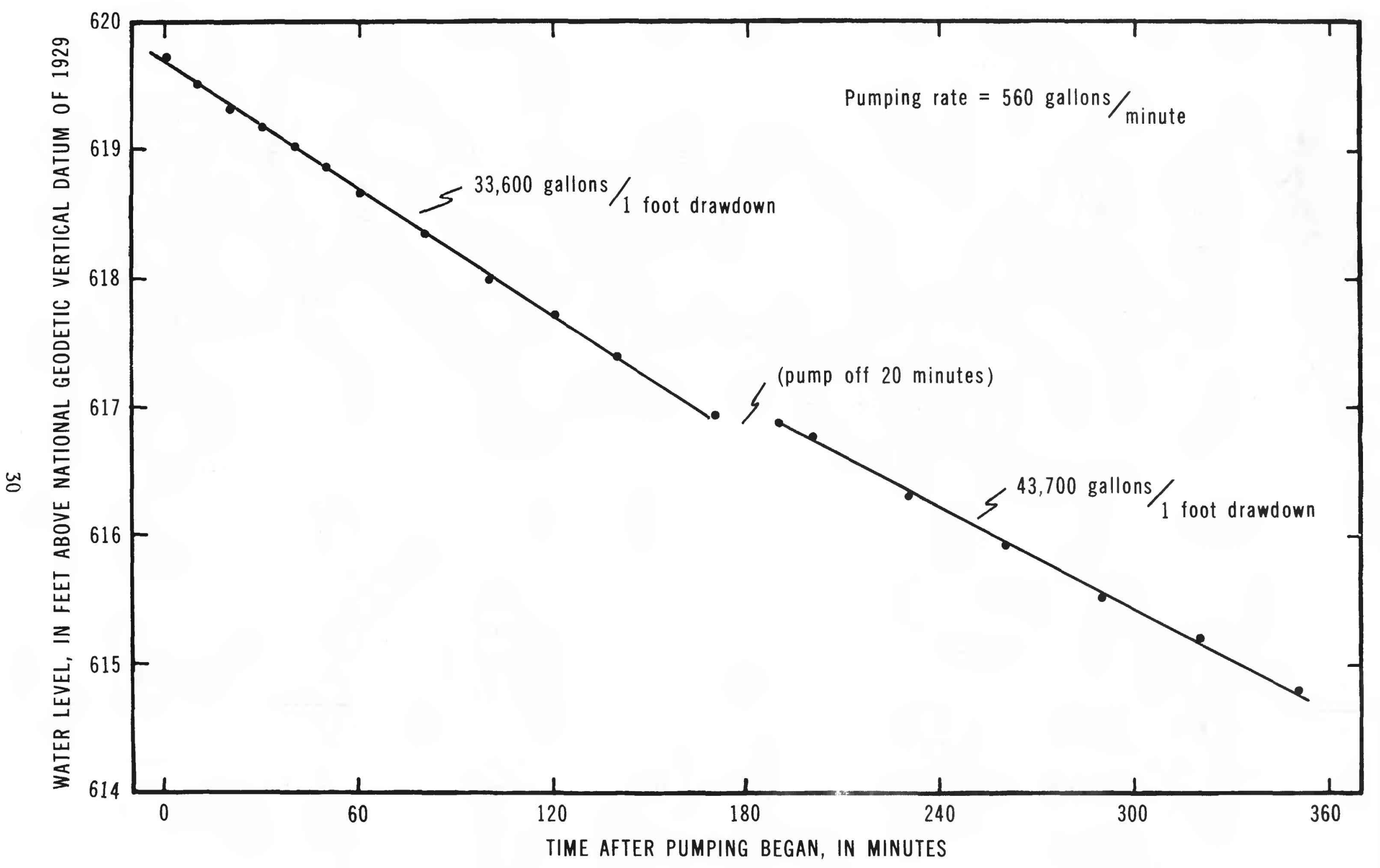

Figure 8 -- Time-drawdown relation, test pumping at site 5, September 20, 1977. 

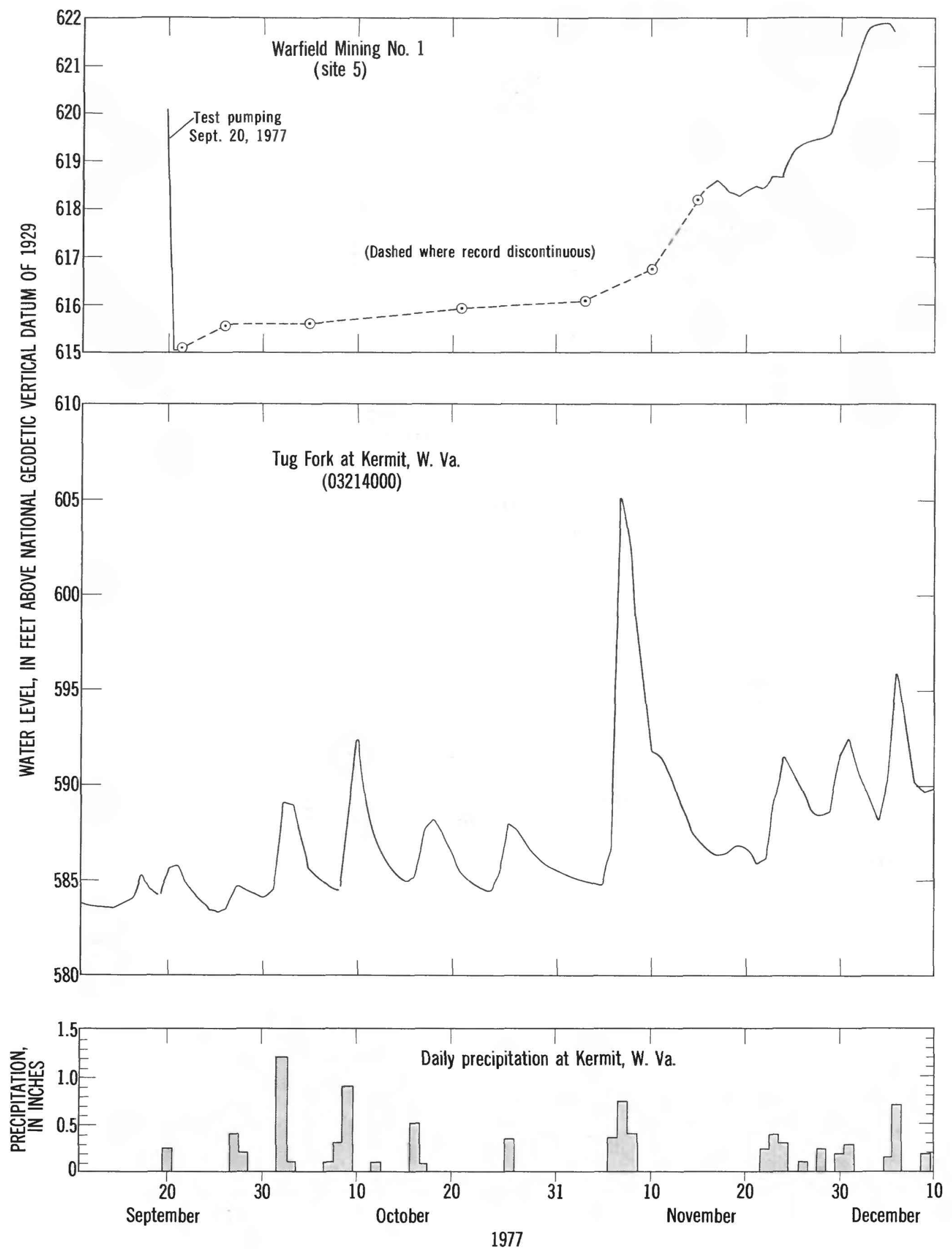

Figure 9.-- Hydrograph of water levels at site 5 after test pumping September 20, 1977, precipitation and stage of the Tug Fork at Kermit, West Virginia. 
galleries was being dewatered. Whatever the cause, when the water reached 616.9 feet, more pumpage was required to lower the free water surface in the mine than during the first part of the test and the slope of the timedrawdown curve decreased. It is 1ikely that the slope of the time-drawdown curve would decrease even more during dewatering if the estimated storage volume of $5.7 \mathrm{M} \mathrm{ft}^{3}$ (million cubic feet) (table 8) is reasonably accurate. This volume would contain about $42.7 \mathrm{Mgal}$ of water. Based on this volume and about 56 feet of available drawdown, a withdrawal rate of 760,000 gallons per foot of drawdown would be required to dewater the mine.

Therefore, the water in storage represents a safety factor sufficient to provide water through periods of limited recharge to the mine. Although the pumping tests indicated that the yield per foot of drawdown was increasing with time, it would take additional pumpage to verify the quantity of water in storage and the shape of the time-drawdown curve. However, the recovery data from this short test does indicate the recharge rates to the mine.

Water-1eve1 recovery in the mine was monitored by an automatic waterlevel recorder. The rate of recovery began to increase around November 3 (fig. 9) and reflects the seasonal ground-water recharge when plants are dormant. The average recovery rate of 1,150 gal/d prior to November 3 was probably due mainly to slow, horizontal movement of water from the regional ground-water body. Direct infiltration of precipitation was probably of minor importance. After November 3, however, the increased recovery rate is probably the result of an increase in recharge from precipitation. For example, during the period November 3-17, the average recovery rate was $6,630 \mathrm{gal} / \mathrm{d}$. If the component from the regional ground-water body $(1,150$ gal/d) is subtracted, recharge from precipitation amounts to $5,480 \mathrm{gal} / \mathrm{d}$. For the entire mined-out area $\left(2.28 \times 10^{6} \mathrm{ft}^{2}\right)$ this recharge rate is 0.0039 in/d or 3.6 percent of the 1.5 inches of precipitation during the 14-day period. The recovery period from November 21 - December 5 can be analyzed in a similar manner. Average recovery rate $(5,260 \mathrm{gal} / \mathrm{d})$ minus the regional ground-water component $(1,150 \mathrm{gal} / \mathrm{d})$ equals a recharge rate of $4,110 \mathrm{gal} / \mathrm{d}$ which represents $0.0029 \mathrm{in} / \mathrm{d}$ or 1.4 percent of the 2.9 inches of precipitation during the period.

A second pumping test was run at Site 5 on March 6, 1978, to observe recharge to the mine during the wetter spring months. Drawdown and recovery data are shown for this test on figure 10. The water level drawdown in the slope was approximately the same as in the September 20th test. Unlike the previous test, however, the water level recovered rapidly as water from a series of rains, which closely followed the test, recharged the mine. The water level in the mine recovered to pre-pumpage levels in 2 days, which corresponds to an average recovery rate of $103,500 \mathrm{gal} / \mathrm{d}$. If the recovery rate is attributed only to recharge from precipitation moving vertically from the surface, the average recharge rate for the 2 days following the March 6 pumping test was $0.073 \mathrm{in} / \mathrm{d}$. The total recharge of 0.15 inches equals 21 percent of the 0.7 inches of rain falling on March 7 and 8 . 

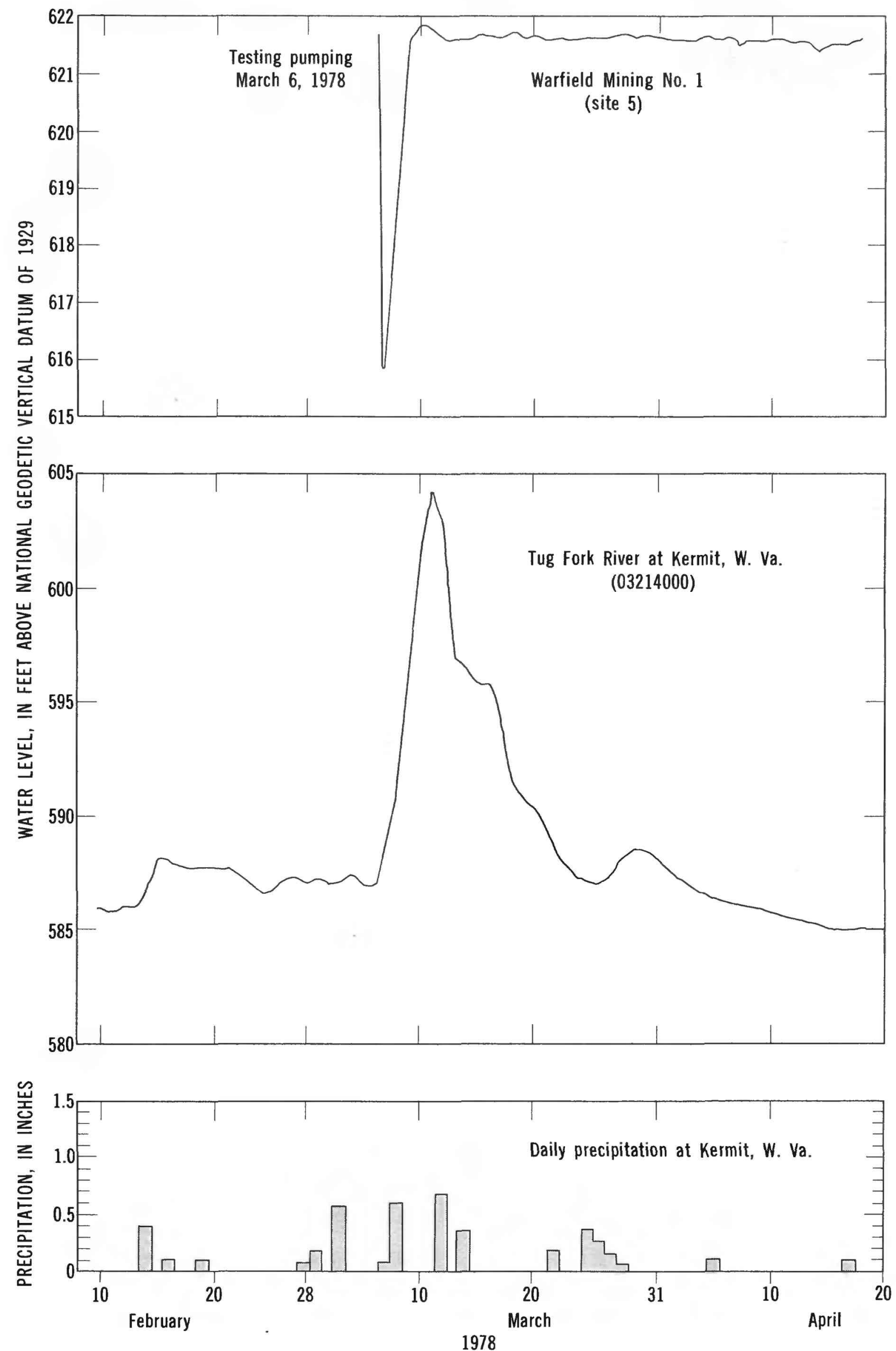

Figure 10.-- Hydrograph of water levels at site 5 after test pumping March 6, 1978, precipitation and stage of the Tug Fork at Kermit, West Virginia. 


\section{Results of Test Pumping at Site 58}

The M and P Coal Company Mine No. 1 (site 58) was pumped from a flooded air shaft on September 21, 1977. The shaft reportedly extends 18 feet below the surface to the Van Lear coal seam. The mine was abandoned in 1963. At the time of the test, water was flowing from the air shaft at about $10 \mathrm{gal} / \mathrm{min}$ and was being used to water livestock. Thus the duration of the pump test was limited so that mine-discharge would be interrupted for only a short time.

Water was pumped at $580 \mathrm{gal} / \mathrm{min}$ for the first 30 minutes of the test which lowered the water level in the shaft 0.15 feet. Discharge was increased to $620 \mathrm{gal} / \mathrm{min}$ for the remaining 80 minutes which resulted in lowering the water level an additional 0.73 feet. A total of 67,000 gallons was pumped during the test. Water level in the shaft recovered to the prepumping leve1 4 days after pumping stopped. The recovery represents the addition of 67,000 gallons of water to the mine from regional ground-water flow. The average recharge rate to the mine is about $16,750 \mathrm{gal} / \mathrm{d}$ which corresponds closely to the natural discharge of approximately $10 \mathrm{gal} / \mathrm{min}$ observed prior to the test.

\section{QUALITY OF WATER IN COAL MINES}

The chemical quality of ground water is directly related to the type of material through which it flows and the period of time the water is in contact with the material. Water percolating downward from the land surface reacts with soil and rock to dissolve organic and inorganic matter. This percolating water is commonly of a calcium-magnesium bicarbonate composition and is slightly alkaline. As the water seeps into coal mines it comes in contact with coal and associated rocks and minerals. Thus the chemical quality of water in the mines reflects the chemical character of the rock and soil and the changes in water quality caused by chemical reactions within the coal mine.

Oxygen and water react with the pyrite to form iron sulfate and sulfuric acid. The quantities of iron, acids, and sulfate present in mine water are dependent upon the amount and type of pyrite in the coal and overlying rocks, the amount of oxygen available to react with the pyrite, and the length of contact time for the reactions. The chemical quality of the ground water which infiltrates into a coal mine from overlying rocks is, as mentioned; commonly slightly alkaline, and thus has a high capacity to neutralize the acid being produced by pyrite oxidation in the coal mine. Formation of acid-mine water is often prevented naturally in this manner.

\section{General Water Quality from a11 Mines}

Analyses of mine water sampled in Johnson and Martin Counties are listed in tables 9 and 10 and illustrated by Stiff diagrams on plates 1 and 2. The Stiff diagram provides a quick comparison of the chemical character 
Table 9.--Chemical analyses of mine water from selected sites in Martin County

(Chemical constituents are in milligrams per liter except where noted)

\begin{tabular}{|c|c|c|c|c|c|c|c|c|c|c|c|c|c|c|c|c|c|c|c|c|c|c|}
\hline $\begin{array}{l}\text { Site } \\
\text { number }\end{array}$ & $\begin{array}{l}\text { Date of } \\
\text { collec- } \\
\text { tion }\end{array}$ & $\begin{array}{l}\text { Dis- } \\
\text { charge } \\
\text { (gal/min) }\end{array}$ & $\begin{array}{l}\text { Silica } \\
\left(\mathrm{SiO}_{2}\right)\end{array}$ & $\begin{array}{l}\text { Ca1- } \\
\text { cium } \\
(\mathrm{Ca})\end{array}$ & $\begin{array}{l}\text { Mag- } \\
\text { ne- } \\
\text { sium } \\
\text { (Mg) }\end{array}$ & $\begin{array}{l}\text { So- } \\
\text { dium } \\
(\mathrm{Na})\end{array}$ & $\begin{array}{l}\text { Po- } \\
\text { tas } \\
\text { sium } \\
(\mathrm{K})\end{array}$ & $\begin{array}{l}\text { Dis- } \\
\text { solved } \\
\text { iron } \\
(\mathrm{Fe})\end{array}$ & $\begin{array}{c}\text { Total } \\
\text { iron } \\
(\mathrm{Fe})\end{array}$ & $\begin{array}{l}\text { Dis- } \\
\text { solved } \\
\text { manga- } \\
\text { nese } \\
(\mathrm{Mn})\end{array}$ & $\begin{array}{l}\text { Tota1 } \\
\text { manga- } \\
\text { nese } \\
(\mathrm{Mn})\end{array}$ & $\begin{array}{l}\text { Bicar- } \\
\text { bonate } \\
\left(\mathrm{HCO}_{3}\right)\end{array}$ & $\begin{array}{l}\text { Aci- } \\
\text { dity } \\
(\mathrm{H}+)\end{array}$ & $\begin{array}{l}\text { Sul- } \\
\text { fate } \\
\left(\mathrm{SO}_{4}\right)\end{array}$ & $\begin{array}{l}\text { Ch1o- } \\
\text { ride } \\
\text { (CI) }\end{array}$ & $\begin{array}{l}\text { Fluo- } \\
\text { ride } \\
\text { (F) }\end{array}$ & $\begin{array}{l}\text { Dis- } \\
\text { solved } \\
\text { solids } \\
\text { (Res- } \\
\text { idue at } \\
180^{\circ} \mathrm{C} \text { ) }\end{array}$ & $\begin{array}{l}\text { Hardne } \\
\text { as } \mathrm{Ca} \\
\text { Non- } \\
\text { carbon- } \\
\text { ate }\end{array}$ & $\begin{array}{l}\mathrm{ess} \\
\mathrm{CO}_{3} \\
\mathrm{Ca}-\mathrm{Mg}\end{array}$ & $\begin{array}{l}\text { Specific } \\
\text { conduc- } \\
\text { tance } \\
\text { (micro- } \\
\text { mhos } \\
\text { per cm } \\
\text { at } 25{ }^{\circ} \text { ) }\end{array}$ & $\begin{array}{c}\text { Field } \\
\text { pH } \\
\text { (units) }\end{array}$ & $\begin{array}{l}\text { Field } \\
\text { tem- } \\
\text { pera- } \\
\text { ture } \\
\left({ }^{\circ} \mathrm{C}\right)\end{array}$ \\
\hline 1 & $6-9-76$ & NF & 13 & 27 & 6.6 & 26 & 3.5 & 1.7 & 3.2 & 0.50 & 0.50 & 80 & 0 & 54 & 18 & 0.2 & 184 & 29 & 95 & 305 & 6.1 & $\sqrt{12}$ \\
\hline $1^{*}$ & $8-31-77^{a} /$ & / NF & 8.7 & 7.3 & 2.4 & 2.3 & 1.4 & .08 & .54 & .00 & .04 & 17 & 0 & 19 & 1.5 & .1 & 51 & 14 & 28 & 84 & 6.5 & 15 \\
\hline 2 & $12-21-77$ & 125 & 22 & 84 & 34 & 300 & 10 & 51. & 51. & 1.6 & 1.6 & 0 & 0 & 870 & 16 & .2 & 1,530 & 350 & 350 & 2,180 & 4.7 & 10 \\
\hline $3^{*}$ & $12-21-77$ & 34 & 15 & 76 & 32 & 260 & 10 & 63. & 63. & 1.3 & 1.3 & 42 & 0 & 780 & 150 & .1 & 1,360 & 290 & 320 & 2,040 & 5.7 & 14 \\
\hline 5 & $6-9-76$ & $\mathrm{NF}$ & 9.6 & 32 & 13 & 13 & 3.3 & .26 & 32. & .41 & .60 & 82 & 0 & 92 & 4.2 & .6 & 222 & 66 & 130 & 338 & 4.5 & 13 \\
\hline $5^{*}$ & $9-20-77^{b} /$ & $/ \mathrm{NF}$ & 11 & 110 & 36 & 27 & 8.2 & - & 16. & .04 & 1.5 & 140 & 0 & 330 & 4.1 & .2 & 608 & 310 & 420 & 874 & 6.4 & 13 \\
\hline $9^{*}$ & $7-14-76$ & $\mathrm{NF}$ & 19 & 40 & 14 & 17 & 2.0 & 13. & - & .69 & - & 160 & 0 & 55 & 2.9 & .2 & 236 & 26 & 160 & 375 & 8.6 & 11 \\
\hline $18^{*}$ & $7-14-76$ & - & 6.1 & 99 & 31 & 110 & 16 & .57 & - & .72 & - & 360 & 0 & 320 & 13 & .3 & 758 & 80 & 370 & 1,150 & 6.3 & 17 \\
\hline
\end{tabular}

a/ Sampled after pumping 9 hours at $10 \mathrm{gal} / \mathrm{min}$.

b/ Sampled after pumping $6-1 / 2$ hours at $560 \mathrm{gal} / \mathrm{min}$.

* Stiff diagram for these analyses shown in Plate 2 .

NF No flow. 
Table 10.--Chemical analyses of mine water from selected sites in Johnson County Chemical constituents are in milligrams per liter except where noted)

\begin{tabular}{|c|c|c|c|c|c|c|c|c|c|c|c|c|c|c|c|c|c|c|c|c|c|c|}
\hline $\begin{array}{l}\text { Site } \\
\text { number }\end{array}$ & $\begin{array}{l}\text { Date of } \\
\text { collec- } \\
\text { tion }\end{array}$ & $\begin{array}{l}\text { Dis- } \\
\text { charge } \\
\text { (gal/min) }\end{array}$ & $\begin{array}{l}\text { Silica } \\
\left(\mathrm{SiO}_{2}\right)\end{array}$ & $\begin{array}{l}\text { Cal- } \\
\text { cium } \\
\text { (Ca) }\end{array}$ & $\begin{array}{l}\text { Mag- } \\
\text { ne- } \\
\text { sium } \\
(\mathrm{Mg})\end{array}$ & $\begin{array}{l}\text { So- } \\
\text { dium } \\
\text { (Na) }\end{array}$ & $\begin{array}{l}\text { Po- } \\
\text { tas- } \\
\text { sium } \\
\text { (K) }\end{array}$ & $\begin{array}{l}\text { Dis- } \\
\text { so1ved } \\
\text { iron } \\
(\mathrm{Fe})\end{array}$ & $\begin{array}{c}\text { Total } \\
\text { iron } \\
(\mathrm{Fe})\end{array}$ & $\begin{array}{l}\text { Dis- } \\
\text { solved } \\
\text { manga- } \\
\text { nese } \\
(\mathrm{Mn})\end{array}$ & $\begin{array}{l}\text { Tota1 } \\
\text { manga- } \\
\text { nese } \\
(\mathrm{Mn})\end{array}$ & $\begin{array}{l}\text { Bicar- } \\
\text { bonate } \\
\left(\mathrm{HCO}_{3}\right)\end{array}$ & $\begin{array}{l}\text { Aci- } \\
\text { dity } \\
(\mathrm{H}+)\end{array}$ & $\begin{array}{l}\text { Sul- } \\
\text { fate } \\
\left(\mathrm{SO}_{4}\right)\end{array}$ & $\begin{array}{l}\text { Chlom } \\
\text { ride } \\
\text { (C1) }\end{array}$ & $\begin{array}{l}\text { F1uo- } \\
\text { ride } \\
\text { (F) }\end{array}$ & $\begin{array}{l}\text { Dis- } \\
\text { solved } \\
\text { solids } \\
\text { (Res- } \\
\text { idue at } \\
180^{\circ} \mathrm{C} \text { ) }\end{array}$ & $\begin{array}{l}\text { Hardn } \\
\text { as Ca } \\
\text { Non- } \\
\text { carbon- } \\
\text { ate }\end{array}$ & $\begin{array}{l}\text { ess } \mathrm{SO}_{3} \\
\mathrm{CO}_{3} \\
\mathrm{Ca}-\mathrm{Mg}\end{array}$ & $\begin{array}{c}\text { Specific } \\
\text { conduc- } \\
\text { tance } \\
\text { (micro- } \\
\text { mhos } \\
\text { per cm } \\
\text { at } 25^{\circ} \mathrm{C} \text { ) } \\
\end{array}$ & $\begin{array}{c}\text { Field } \\
\text { pH } \\
\text { (units) }\end{array}$ & $\begin{array}{l}\text { Field } \\
\text { tem- } \\
\text { pera- } \\
\text { ture } \\
\left({ }^{\circ} \mathrm{C}\right)\end{array}$ \\
\hline $21^{*}$ & $6-10-76$ & 40 & 15 & 90 & 47 & 28 & 7.3 & 0.02 & - & 0.04 & - & 48 & 0 & 420 & 2.3 & 0.3 & 664 & 380 & 420 & 874 & 7.4 & 14 \\
\hline 21 & $12-20-77$ & 49 & 14 & 85 & 43 & 26 & 7.6 & .04 & 0.26 & .14 & 0.14 & 29 & 0 & 420 & 1.9 & .2 & 628 & 370 & 390 & 861 & 6.4 & 13 \\
\hline $22^{*}$ & $6-30-76$ & 50 & 15 & 71 & 32 & 45 & 6.0 & .12 & 5.7 & .33 & .58 & 10 & 0 & 410 & 1.8 & .3 & 634 & 300 & 310 & 816 & 5.7 & 14 \\
\hline 22 & $12-20-77$ & 47 & 16 & 83 & 38 & 68 & 7.7 & .11 & .32 & .36 & .36 & 20 & 0 & 480 & 2.2 & .2 & 749 & 350 & 360 & 1,010 & 5.5 & 13 \\
\hline $23^{*}$ & $6-10-76$ & 13 & 22 & 67 & 32 & 55 & 5.5 & 1.2 & 8.0 & 1.4 & 1.4 & 0 & 1.0 & 460 & 1.6 & .5 & 704 & 300 & 300 & 999 & 4.0 & 13 \\
\hline $24^{*}$ & $12-20-77$ & 18 & 24 & 66 & 36 & 34 & 5.0 & 2.5 & 2.5 & 3.2 & 3.2 & 0 & 2.2 & 460 & 1.4 & .3 & 677 & 310 & 310 & 1,090 & 3.8 & 12 \\
\hline $26^{*}$ & $6-10-76$ & 4 & 9.4 & 61 & 40 & 10 & 4.4 & .34 & 6.4 & .26 & .30 & 0 & 0 & 320 & 2.9 & .3 & 518 & 320 & 320 & 655 & 4.8 & 15 \\
\hline 26 & $12-20-77$ & 4 & 18 & 68 & 42 & 13 & 5.4 & .30 & .43 & .58 & .58 & 0 & 0 & 380 & 2.8 & .2 & 571 & 340 & 340 & 802 & 4.8 & 10 \\
\hline $27^{*}$ & $8-11-76$ & 17 & 11 & 190 & 89 & 120 & 9.0 & .01 & .76 & .13 & .27 & 42 & 0 & 1,000 & 2.7 & .2 & 1,560 & 810 & 840 & 1,820 & 4.5 & 14 \\
\hline 27 & $1-5-78$ & 27 & 14 & 210 & 92 & 100 & 9.2 & .02 & .17 & .51 & .51 & 34 & 0 & 1,000 & 2.3 & .2 & 1,350 & 880 & 900 & 2,140 & 6.0 & 14 \\
\hline $28^{*}$ & $6-10-76$ & 9 & 16 & 88 & 46 & 18 & 5.0 & .14 & 3.4 & 4.0 & 5.0 & 3 & 0 & 460 & 1.0 & .6 & 680 & 410 & 410 & 855 & 4.0 & 13 \\
\hline 28 & $12-20-77$ & 12 & 11 & 110 & 53 & 30 & 7.4 & .02 & .47 & .26 & .44 & 120 & 0 & 440 & 2.4 & .2 & 759 & 390 & 490 & 1,010 & 6.9 & 9 \\
\hline $41^{*}$ & $1-5-78$ & 17 & 41 & 140 & 73 & 19 & 6.0 & 9.7 & 9.7 & 4.0 & 4.0 & 0 & 3.0 & 760 & 1.4 & .3 & 1,120 & 650 & 650 & 1,750 & 3.9 & 13 \\
\hline $42^{*}$ & $6-29-76$ & 9 & 19 & 50 & 31 & 20 & 7.0 & 7.0 & 7.9 & 2.0 & 2.0 & 0 & 1.7 & 360 & 2.0 & .4 & 556 & 250 & 250 & 874 & 3.7 & 15 \\
\hline $47^{*}$ & $9-1-77$ & NF & 17 & 32 & 11 & 58 & 5.8 & 1.8 & 1.8 & .57 & .57 & 160 & 0 & 60 & 17 & .3 & 312 & 0 & 130 & 550 & 6.7 & 13 \\
\hline $52^{*}$ & $6-30-76$ & $\mathrm{NF}$ & 33 & 93 & 56 & 140 & 5.5 & 11. & 12 . & 1.7 & 1.4 & 0 & 1.0 & 910 & 2.4 & .8 & 1,380 & 460 & 460 & 1,830 & 3.5 & 1.3 \\
\hline $54^{*}$ & $6-29-76$ & $\mathrm{NF}$ & 38 & 100 & 36 & 6.6 & 3.3 & 64. & 69. & 2.8 & 2.8 & 0 & 7.1 & 770 & 1.8 & .8 & 1,180 & 400 & 400 & 1,750 & 3.1 & 16 \\
\hline 58 & $6-29-76$ & - & 11 & 39 & 17 & 37 & 8.0 & .23 & 24 . & .05 & .20 & 99 & 0 & 170 & 2.6 & .3 & 249 & 86 & 170 & 531 & 6.5 & 15 \\
\hline $58^{*}$ & $9-21-77^{a} /$ & $1-$ & 9.8 & 36 & 17 & 29 & 7.6 & .03 & .21 & .01 & .01 & 75 & 0 & 160 & 1.5 & .1 & 300 & 98 & 160 & 468 & 6.5 & 13 \\
\hline 58 & $12-19-77$ & 20 & 11 & 32 & 14 & 20 & 6.0 & .08 & .17 & .03 & .03 & 54 & 0 & 140 & 2.1 & .1 & 350 & 93 & 140 & 388 & 6.2 & 13 \\
\hline $59^{*}$ & $6-29-76$ & 10 & 11 & 52 & 25 & 36 & 9.0 & .01 & 2.0 & .08 & .28 & 41 & 0 & 290 & 2.1 & .3 & 460 & 200 & 230 & 664 & 7.2 & 14 \\
\hline 59 & $12-19-77$ & 9 & 11 & 55 & 24 & 42 & 10 & .04 & .45 & .12 & .32 & 55 & 0 & 280 & 2.4 & .2 & 455 & 190 & 240 & 686 & 6.9 & 13 \\
\hline $60^{*}$ & $6-29-76$ & $\mathrm{NF}$ & 19 & 24 & 18 & 7.0 & 2.7 & .01 & .11 & .56 & .60 & 2 & 0 & 140 & 1.5 & .3 & 216 & 130 & 130 & 328 & 5.9 & 14 \\
\hline $66^{*}$ & $7-15-76$ & 8 & 25 & 69 & 37 & 11 & 7.5 & 14. & 15. & 1.3 & 1.4 & 0 & 1.1 & 380 & 2.7 & .5 & 584 & 320 & 320 & 880 & 4.2 & 21 \\
\hline 66 & $12-21-77$ & 8 & 23 & 66 & 35 & 11 & 7.0 & 5.4 & 7.3 & 1.3 & 1.3 & 0 & 1.2 & 350 & 1.9 & .2 & 509 & 310 & 310 & 820 & 4.1 & 12 \\
\hline $73^{*}$ & $8-12-76$ & $\mathrm{NF}$ & 8.1 & 30 & 6.1 & 27 & 15 & .69 & 31. & .04 & .08 & 84 & 0 & 64 & 19 & .2 & 256 & 31 & 100 & 382 & 7.0 & 17 \\
\hline 73 & $12-21-77$ & $N F$ & 9.2 & 20 & 6.8 & 10 & 3.1 & .03 & 36. & .02 & .30 & 21 & 0 & 49 & 11 & .0 & 138 & 61 & 78 & 234 & 6.7 & 13 \\
\hline $74^{*}$ & $6-8-76$ & - & 9 & 57 & 21 & 440 & 12 & .03 & .70 & .18 & .18 & 616 & 0 & 320 & 230 & .6 & 1,380 & 0 & 230 & 2,210 & - & 14 \\
\hline 74 & $12-21-77$ & - & 9.6 & 51 & 18 & 390 & 10 & .42 & .67 & .14 & .14 & 620 & 0 & 280 & 220 & .4 & 1,250 & 0 & 200 & 2,120 & 7.2 & 14 \\
\hline $75 *$ & $7-13-76$ & $\mathrm{NF}$ & 16 & 23 & 7.8 & 180 & 4.8 & .11 & .49 & .05 & .05 & 375 & 0 & 34 & 110 & .5 & 558 & 0 & 90 & 970 & 8.0 & 17 \\
\hline $76^{*}$ & $8-12-76$ & $\mathrm{NF}$ & 11 & 48 & 15 & 8.2 & 4.3 & .05 & 61. & .38 & 1.3 & 91 & 0 & 110 & 3.3 & .2 & 262 & 110 & 180 & 400 & 6.2 & 15 \\
\hline
\end{tabular}

a/ Sampled after pumping 2 hours at $600 \mathrm{gal} / \mathrm{min}$.
Stiff diagrams for these analyses shown in Plate 1.

NF No flow. 
of mine waters; the shape of the diagram indicates chemical composition while the size of the diagram represents the ionic strength of the principal anions and cations in solution. Dissolved calcium, magnesium, and sulfate are predominant in most of the mine waters in the study area. The calciummagnesium-sulfate water is the product of pyrite dissolution coupled with the neutralizing action of the calcium and magnesium bicarbonates in the natural ground-water system.

Most of the mine waters are similar chemically; that is, the relative proportions of dissolved constituents are similar between different mines (note the similarity of shapes of Stiff diagrams, plates 1 and 2). The absolute concentrations of dissolved constituents, however, vary significantly between sites (note size variations of Stiff diagrams, plates 1 and 2).

The maximum, minimum, and median values of the dissolved constituents and chemical quality characteristics for all mine waters sampled are listed in table 11. The source and significance of dissolved-mineral constituents are discussed on table 12. Note that concentrations of hardness, sulfate, iron, and manganese found in some mine waters may render the water objectionable for some uses if not treated.

Mine waters having a different chemistry from the calcium magnesium sulfate type were sampled from sites 2, 3, 74, and 75. Water from these mines clearly shows a sodium chloride overprint on the basic calcium magnesium sulfate chemistry. The sodium chloride water is probably from deeper aquifers saturated with brackish water. The brackish fluids may have migrated upward in oil and gas wells which penetrate both the Consolidation Coal Company's mines (sites 74, 75) and the Himmler-Earlston Mines (sites 2, 3).

In addition to the major inorganic elements, samples from selected sites were analyzed for phenols. The maximu allowable concentration of phenols in drinking water is $1 \mathrm{\mu g} / \mathrm{L}$ (microgram per 1iter). (Kentucky Department of Natural Resources and Environmental Protection, 1977). Results of analyses are listed below:

$\begin{array}{rc}\text { Site } & \begin{array}{c}\text { Phenols } \\ \mu \mathrm{g} / \mathrm{L}\end{array} \\ 3 & 0 \\ 5 & 5 \\ 21 & 1 \\ 22 & 2 \\ 24 & 0 \\ 27 & 0 \\ 41 & 0 \\ 58 & 1\end{array}$

Although phenolic compounds arise from a number of naturally occurring sources and substances, in this case the phenolic compounds are assumed to indicate the level of coal-derived constituents in mine waters. Phenolic 
Table 11.--Maximum, minimum, and median values of water characteristics for all samples

\begin{tabular}{|c|c|c|c|}
\hline Parameter & Median & Maximum & Minimum \\
\hline $\begin{array}{l}\text { Specific conductance } \\
\text { (micromhos per } \mathrm{cm} \text { at } \\
25^{\circ} \mathrm{C} \text { ) }\end{array}$ & 859 & 2,210 & 84 \\
\hline pH (units) & 6.1 & 8.0 & 3.1 \\
\hline Temperature ${ }^{\circ} \mathrm{C}$ & 13.8 & 24 & 9 \\
\hline Calcium & 61 & 210 & 7.3 \\
\hline Magnesium & 25 & 92 & 2.4 \\
\hline Sodium & 27 & 440 & 2.3 \\
\hline Potassium & 7.1 & 16 & 1.4 \\
\hline Dissolved iron & 0.25 & 64 & 0.01 \\
\hline Total iron & 3.0 & 69 & 0.11 \\
\hline Dissolved manganese & 0.34 & 4.0 & 0.00 \\
\hline Total manganese & 0.39 & 5.0 & 0.01 \\
\hline Acidity (as $\left.\mathrm{H}^{+}\right)$ & 0 & 7.1 & 0 \\
\hline Bicarbonate & 38 & 620 & 0 \\
\hline Sulfate & 310 & 1,000 & 19 \\
\hline Chloride & 2.8 & 230 & 1.0 \\
\hline Fluoride & 0.25 & 0.8 & 0.0 \\
\hline $\begin{array}{l}\text { Calcium magnesium } \\
\text { hardness (as } \mathrm{CaCO}_{3} \text { ) }\end{array}$ & 225 & 900 & 28 \\
\hline $\begin{array}{l}\text { Non-carbonate hard- } \\
\text { ness (as } \mathrm{CaCO}_{3} \text { ) }\end{array}$ & 192 & 880 & 0 \\
\hline $\begin{array}{l}\text { Dissolved solids } \\
\text { (residue at } 180^{\circ} \mathrm{C} \text { ) }\end{array}$ & 608 & 1,560 & 51 \\
\hline Silica & 13 & 41 & 6.1 \\
\hline
\end{tabular}

Concentrations in milligrams per liter unless noted 
Table 12.--Source and significance of dissolved mineral constituents and physical properties of natural waters

Constituent
physical proper
Bicarbonate $\left(\mathrm{HCO}_{3}\right)$
Carbonate $\left(\mathrm{CO}_{3}\right)$

Calcium (Ca) and
Magnesium (Mg)

Magnesium (Mg)

Chloride (C1)

Fluoride (F)

Iron $(\mathrm{Fe})$

Manganese $(\mathrm{Mn})$

Silica $\left(\mathrm{SiO}_{2}\right)$

Source or cause

Significance

Action of carbon dioxide in water on carbonate rocks such as limestone and dolomite.

Dissolved from practically all soils and rocks, but especially from limestone, dolomite, and gypsum. Calcium and magnesium are found in large quantities in some brines. Magnesium is present in large quantities in sea water.

Dissolved from rocks and soils. Present in sewage and found in large amounts in ancient brines, sea water, and industrial brines.

Dissolved in small to minute quantities from most rocks and soils.

Dissolved from practically all rocks and soils. May also be derived from iron pipes, pumps, and other equipment. More than 1 or $2 \mathrm{mg} / \mathrm{L}$ of soluble iron in surface waters usually indicates acid wastes from mine drainage or other sources.

Dissolved from some rocks and soils. Not so common as iron. Large quantities often associated with high iron content and with acid waters.

Dissolved from practically all rocks and soils, usualiy in small amounts from 1 to $50 \mathrm{mg} / \mathrm{L}$. High concentrations, as much as $100 \mathrm{mg} / \mathrm{L}$, generally occur in highly alkaline waters.
Bicarbonate and carbonate produce alkalinity. Bicarbonates of calcium and magnesium decompose in steam boilers and hot water facilities to form scale and release corrosive carbon dioxide gas. In combination with calcium and magnesium cause carbonate hardness.

Causes most of the hardness and scaleforming properties of water; soap consuming (see hardness). Waters low in calcium and magnesium desired in electroplating, tanning, dyeing, and in textile manufacturing.

In large amounts in combination with sodium gives salty taste to drinking water. In large quantities increases the corrosiveness of water. Drinking water standards recommend that the chloride content should not exceed 250 $\mathrm{mg} / \mathrm{L}$ on the basis of taste preferences.

Fluoride in drinking water reduces the incidence of tooth decay when the water is consumed during the period of enamel calcification. However, it may cause mottling of the teeth depending on the concentration of fluoride, the age of the child, amount of drinking water consumed, and susceptibility of the individual. (Maier, F. J., 1950, Fluoridation of public water supplies: Journal American Water Works Association, v. 42, pt. 1, p. 1120-1132.)

On exposure to air, iron in ground water oxidizes to reddish-brown sediment. More than about $0.3 \mathrm{mg} / \mathrm{L}$ stains laundry and utensils. Objectionable for food processing, beverages, dyeing, bleaching, ice manufacture, brewing, and other processes. Federal drinking water standards recommend that soluble iron and manganese together should not exceed $0.3 \mathrm{mg} / \mathrm{L}$. Larger quantities cause unpleasant taste and favor growth of iron bacteria.

Same objectionable features as iron. Causes dark brown or black stain. Federal drinking water standards recommend that soluble iron and manganese together should not exceed $0.3 \mathrm{mg} / \mathrm{L}$.

Forms hard scale in pipes and boilers. Carried over in steam of high-pressure boilers to form deposits on blades of steam turbines. Inhibits deterioration of zeolite-type water softeners. 
Table 12.--Source and significance of dissolved mineral constituents and physical properties of natural waters--Continued

Constituent or physical property

Sodium $(\mathrm{Na})$ and

Potassium (K)

Sulfate $\left(\mathrm{SO}_{4}\right)$

Dissolved solids

Hardness as $\mathrm{CaCO}_{3}$

Hydrogen-ion concentration $(\mathrm{pH})$

Specific conductance (micromhos per $\mathrm{cm}$ at $25^{\circ} \mathrm{C}$ )
Dissolved from rocks and soils containing gypsum, iron sulfide, and other sulfur compounds. Usually present in mine waters and in some industrial wastes.

Chiefly mineral constituents dissolved from rocks and soils. Includes any organic matter and some water of crystallization.

In most waters noarly all the hardness is due to calcium and magnesium. All of the metallic cations other than the alkali metals also cause hardness.

Acids, acid-generating salts, and free carbon dioxide lower the $\mathrm{pH}$. Carbonates, bicarbonates, hydroxides and phosphates, silicates, and borates raise the $\mathrm{pH}$.

Mineral content of the water.

\section{Significance}

Large amounts, in combination with chloride, give a salty taste. Moderate quantities have little effect on the usefulness of water for most purposes. Sodium salts may cause foaming in steam boilers and a high sodium ration may limit the use of water for irrigation.

Sulfate in water containing calcium forms hard scale in steam boilers. In large amounts, sulfate in combination with other ions gives bitter taste to water. Transients using water having more than 250 $\mathrm{mg} / \mathrm{L}$ of sulfate usually experience laxative effects.

Waters containing more than $1,000 \mathrm{mg} / \mathrm{L}$ of dissolved solids are unsuitable for many purposes.

Consumes soap before a lather will form. Deposits soap curd on bathtubs. Hard water forms scale in boilers, water heaters, and pipes. Hardness equivalent to the bicarbonate and carbonate is called carbonate hardness. Any hardness in excess of this is called noncarbonate hardness. Waters of hardness up to $60 \mathrm{mg} / \mathrm{L}$ are considered soft; $61-120 \mathrm{mg} / \mathrm{L}$, moderately hard; $121-180 \mathrm{mg} / \mathrm{L}$, hard; more than $180 \mathrm{mg} / \mathrm{L}$, very hard.

$\mathrm{A} \mathrm{pH}$ of 7.0 indicates neutrality of a solution. Values higher than 7.0 denote increasing alkalinity; values lower than 7.0 indicate increasing acidity. $\mathrm{pH}$ is a measure of the activity of the hydrogen ions. Corrosiveness of water generally increases with decreasing ph. However, excessively alkaline waters may also attack metals.

Specific conductance is a measure of the capacity of the water to conduct an electric current. Varies with concentration and degree of ionization of the constituents. Varies with temperature; reported at $25^{\circ} \mathrm{C}$. Multiplied by 0.6 approximately equals the dissolved solids.

Affects usefulness of water for many purposes. For most users, a water of uniformly low temperature is desired. Shallow wells show some seasonal fluctuations in water temperature. Ground waters from moderate depths usually are nearly constant in temperature, which is near the mean annual air temperature of the area. In very deep wells the water temperature generally increases on the average about $1^{\circ} \mathrm{F}$ with each 60 -foot increment of depth. Seasonal fluctuations in temperatures of surface waters are comparatively large depending on the depth of water but do not reach the extremes of air temperatures. 
compounds can cause aesthetic problems in drinking-water supplies because phenol is not removed efficiently by conventional water treatment, and the chlorination process can produce persistent odor-producing compounds.

\section{Comparison of Water Quality from Coal Mines Above and Below Drainage}

A significant difference in water chemistry occurs between water in underground mines which are above or below the level of perennial stream drainage. In general, the water from below-drainage mines had lower concentrations of dissolved constituents and higher $\mathrm{pH}$ than water from abovedrainage mines.

The mean of the dissolved constituents concentration of water from mines above drainage (sites $2,3,17,18,21,22,23,24,26,27,28,41$, $42,52,54,59,60,66,74)$ is compared to the mean dissolved constituents concentration of water from mines below drainage (sites 1, 5, 10, 47, 58, $75,76)$ on figure 11. Because chemical concentrations appear to differ between the two groups, the significance of these differences was tested statistically using the Kruskal-Wallis analysis-of-variance test (Sokal and Rolf, 1969). The Kruskal-Wallis analysis of variance tests the hypothesis that the two sampled groups come from populations having the same distribution or, as in this case, that there is no difference in water samples from mines above or below drainage. However, the Kruskal-Wallis test indicated that there is a significant differrence in quality of water from mines above or below drainage. The two groups differed significantly at the 99 percent confidence level for bicarbonate, calcium, magnesium, and sulfate. At a slightly lower level of confidence (95 percent), dissolved solids, fluoride, total manganese and dissolved manganese also tested significantly different between groups.

There are at least two possible reasons why mines below drainage yielded water with lower concentrations of dissolved constituents and higher $\mathrm{pH}$ than water from mines that are above drainage:

(1) After abandonment, mine galleries below drainage usually flood. The flooding limits the amount of atmospheric oxygen which is available to react with pyrite. The lower rate of pyrite oxidation lessens the amount of sulfate, iron, and acidity in solution.

(2) Below-drainage coal mines were sampled from slope and shaft openings where precipitation and surface runoff could easily enter the mine. The introduction of surface runoff dilutes the ground water in the mine. Thus, the water samples collected from some openings might not be representative of the quality of water deeper within the mine. In addition, the techniques used in sampling the below-drainage mines produced samples from only the upper zones within the shaft or slope. Thus, if waters were layered or zoned with the more highly mineralized water at lower levels, the samples would not reflect the chemical character of the deeper water. 


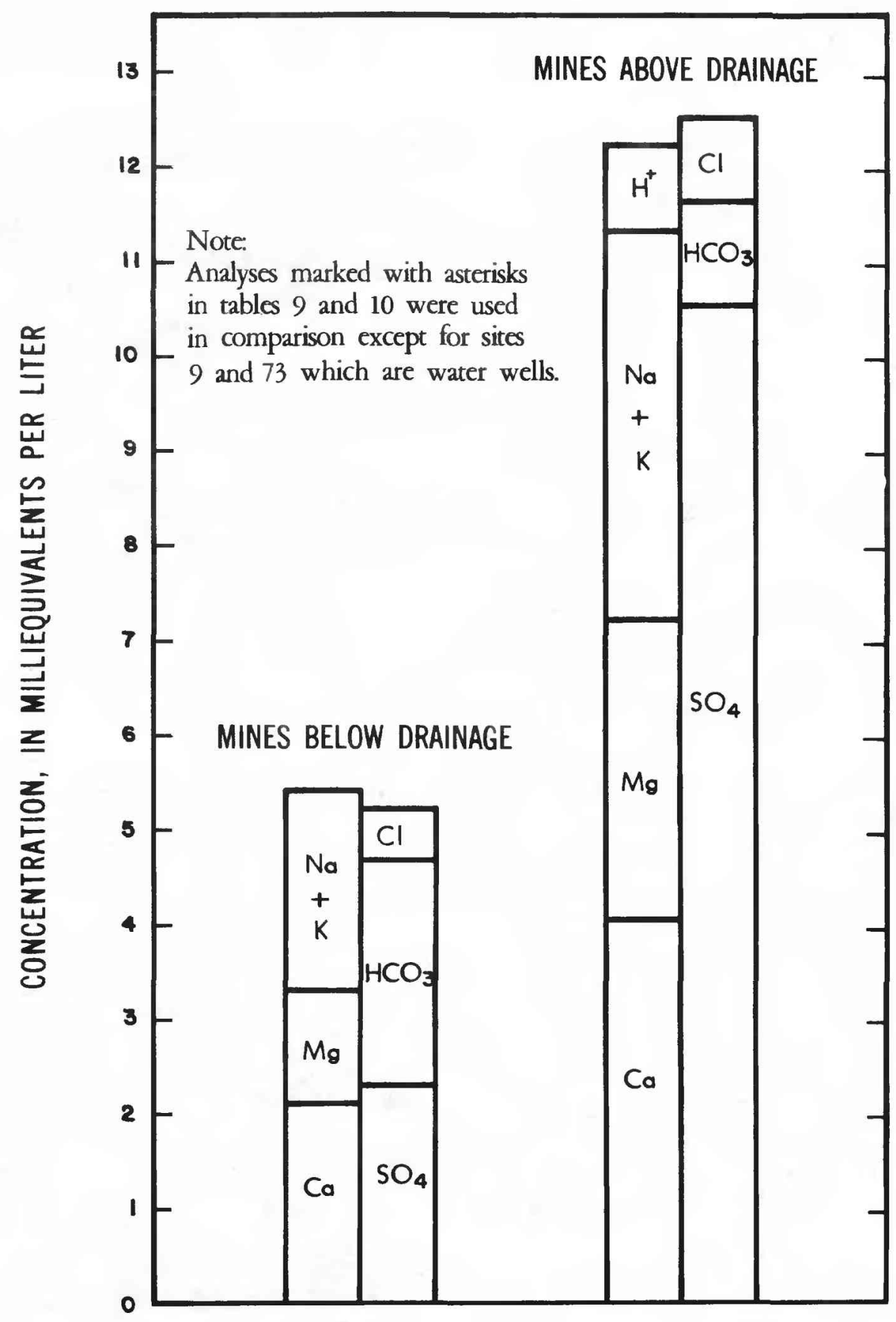

Figure 11. - Comparison of mean dissolved constituents concentration in water from mines above and below drainage. 
The chemical quality of water from a coal mine does not remain constant, but changes in response to seasonal variations in ground water inflow or to pumping. Changes in chemical quality of water may be monitored by a simple field check of its specific conductance. Specific conductance measures the ability of water to conduct an electric current and is directly related to the quantity and type of ions in solution. Because mine waters in the study area generally have the same types of ions in solution, variations in conductance reflect variations in the quantity of ions, the dissolved solids that are in solution. The relation between dissolved solids and specific conductance in the study area is based on 27 samples of mine water and is illustrated on figure 12 . The relation may be expressed analytically as:

$$
\text { dissolved solids concentration }=0.68 \text { (specific conductance })+30.2 \text {. }
$$

The regression of these data has a correlation coefficient of 0.98 . Based on this relation, field measurement of the specific conductance can be used to estimate the dissolved solids concentration of mine water of unknown quality.

\section{Effects of Flow Variations on Water Quality}

The chemical quality of water from underground mines usually varies with the volume of mine discharge. The rate of flow from a mine usually is related to the rapidity of infiltration of water into the mine. The greater the infiltration rate, the greater the flow. Thus the water that passes through the mine at high flow has less contact time for dissolution of the reactive materials within the mine and also dilutes the water already present. To illustrate the changes in water quality which occur as mine discharge varies, specific conductance was measured at various discharges from the North East Coal Company Mine No. 1 at Thealka (site 21). The relation between 16 specific conductance measurements and discharge for site 21 is shown on figure 13. Note the dilution effects at high flows.

A dramatic short-term change of water quality in both surface and underground mines is referred to as a flushout (Corbett and Agnew, 1968). During the dry summer and early fall months, the ground water that seeps into underground mines typically has a relatively long residence time in the mine. Thus the dissolved solids content is high. During the spring months (or after a hard rain) the inflow of ground water to the mine can flush out a slug of the highly mineralized water. Although the flushout phenomonon was not observed during this study, the possibility that water quality can change quickly in this manner should be considered when evaluating a potential water supply from a coal mine. 


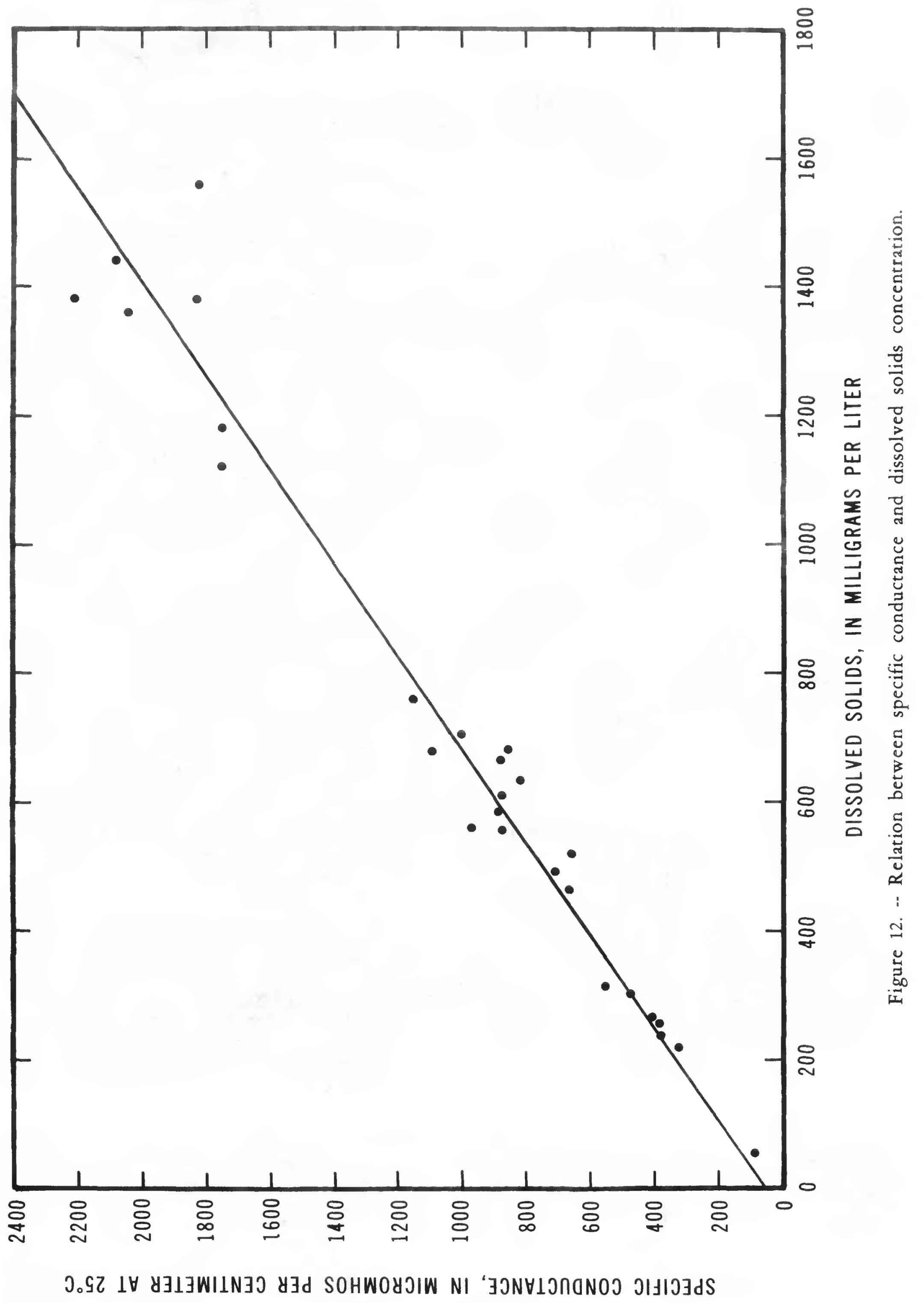




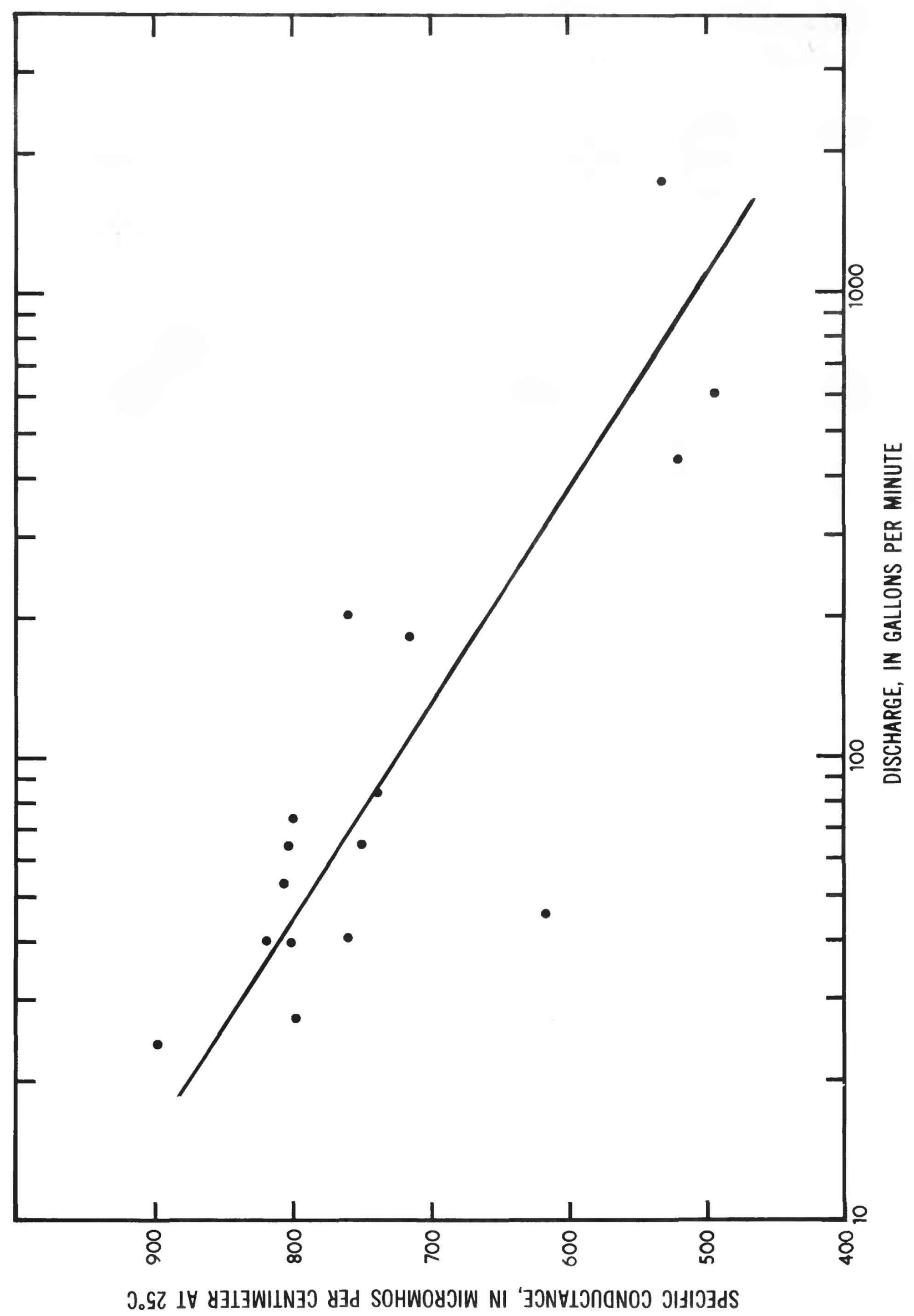

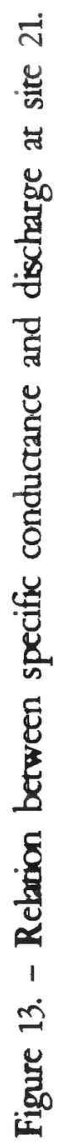

45 


\section{Effects of Pumping on Water Quality}

Changes in water quality can occur when water is pumped from a mine. Pumping may lower the water level in a mine and expose reactive pyrite to atmospheric oxygen. The byproducts of the oxidized pyrite can in turn degrade the mine water by increasing its acidity and dissolved solids content. Over a long period of pumping, the cyclic wetting and reexposure of pyrite to oxygen could alter the water quality significantly.

Changes in water quality will also be observed as water is drawn from successively deeper sections of a mine. In most below-drainage mines which do not have free drainage, water is probably stratified with respect to water quality. That is, the water that lies in the deeper sections of the mine is more highly mineralized due to its longer residence time in the mine. For example, during pumping the Warfield Mining Company Mine No. 1 (site 5) the pumping of more mineralized water at depth probably caused the changes in water quality shown on figure 14 and listed on table 9.

\section{DEVELOPMENT OF WATER SUPPLY FROM UNDERGROUND MINES}

The utilization of water from coal mines depends on a number of factors. Probably the single most important factor is the location of the mine. The cost of constructing a long pipeline may preclude the use of water from mines that are long distances from the point of use.

Water in mines located below drainage can be tapped by drilled wells, but water flowing from above-drainage mines may simply require a pipe from the mouth of the mine.

Wells drilled into below-drainage mines probably offer the safest method of utilizing water from coal mines because sanitary conditions are relatively easy to maintain. In addition below-drainage mines generally yield water of better chemical quality than above-drainage mines that are open to atmospheric oxygen. In mines that are below drainage or in which al1 openings have been sealed, the limited supply of oxygen tends to lessen the acid and sulfate that is produced when pyritic materials oxidize. The shortage of oxygen may be especially beneficial in the case of wetting and drying of pryitic materials caused by cyclic pumping.

Although a pipe laid into the mouth of a self-draining above-drainage mine may be adequate for a small supply, this method may be inadequate during dry weather. In mines with low flow a dam across the mouth can impound water in the mine and sustain flow during dry weather. Abovedrainage mines are usually located high on hillsides, thus water drains by gravity. Obviously, care must be taken to protect the mouth of the mine from contamination. 


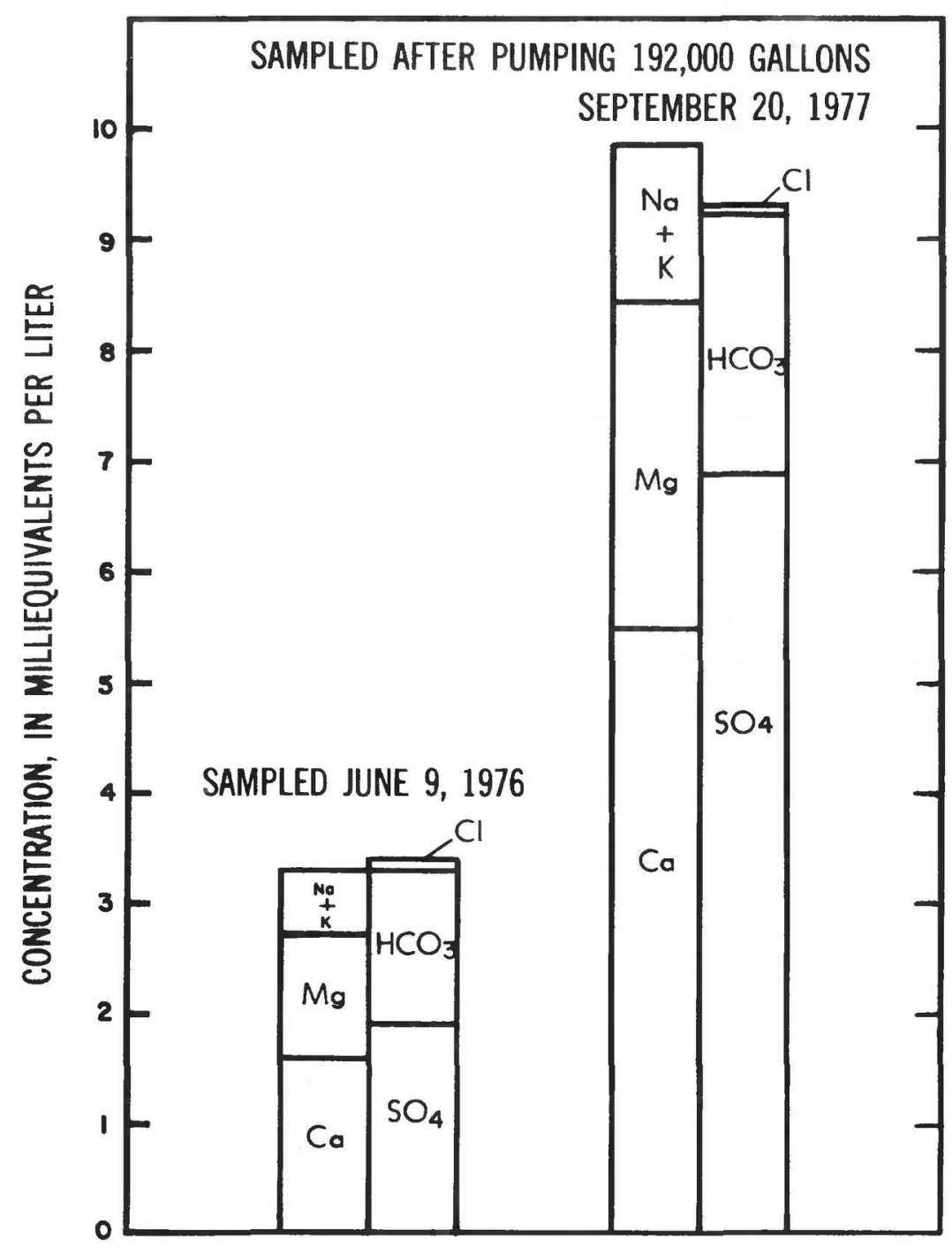

Figure 14 , - Chemical quality of water before and after pumping at site 5. 


\section{SUMMARY}

The water in underground coal mines represents a major ground-water resource in Johnson and Martin Counties. If properly developed, water from these mines could provide dependable supplies for various water needs. The quality and quantity of water available in underground coal mines in the study area may be summarized as follows:

(1) The water-supply capabilities of mines developed above the level of perennial stream drainage can be best estimated by monitoring the seasonal variation of discharge from the mines. Annual discharge from most abovedrainage mines ranged between 3-10 percent of precipitation falling on the mine area during the year. Most above-drainage mine openings which were inventoried were dry or discharged less than $10 \mathrm{gal} / \mathrm{min}$. The highest discharge rate measured from a mine was $1,700 \mathrm{gal} / \mathrm{min}$ from site 21 . The highest sustained rate of discharge was from site 74 which continually discharged between 750 and 1,200 gal/min. Nine other sites provided a yearround flow greater than 10 gal/min (sites 2, 3, 16, 21, 22, 24, 27, 39, and 41).

(2) Mines with the greatest water-supply potential are large mines which were developed below the level of perennial stream drainage. Large, below-drainage mines have extensive recharge areas and contain large quantities of water trapped in storage below drainage. Five large below-drainage mines are located in the study area (sites $1,46,47,76,78$ ).

(3) The amount of water available from mines below drainage can best be estimated by test pumping. For this study two below-drainage mines (sites 5 and 58) were tested with a high-capacity pump. Although the mines at sites 5 and 58 have limited potential as high-capacity water supplies due to their slow recharge rates in the summer months (less than $10 \mathrm{gal} / \mathrm{min}$ ), these mines could be pumped at a somewhat higher rate than the summer recharge rates indicate. The higher rate would need to be based on the volume of water in storage and the rate of replenishment by the higher recharge rates in the winter months. Water-level fluctuations recorded for site 5 revealed a rapid recharge rate to the mine after fall and spring rains. Most mines probably recharge rapidly in this manner as water quickly moves into the mines through fractures in the rock.

Based on the volume of water in storage these mines would be adequate for many sma11 uses or short-term emergency supplies. For example, water from site 5 was used as an emergency supply for the city of Warfield after the flood of April 6, 7, 1977. Water was reportedly pumped 65 minutes per day at $50 \mathrm{gal} / \mathrm{min}$ for a period of 3 weeks. Little drawdown was observed in the mine.

(4) Unless treated, the quality of raw mine water will be objectionable for some uses. The mine waters sampled were typically high in calcium, magnesium, and sulfate with $\mathrm{pH}$ ranging from 3.1 to 8.0 units. High concentrations of iron and manganese were also present in most mine waters. 
(5) Water in below-drainage mines appeared to be less mineralized and less acidic than water from above-drainage mines.

(6) Water from coal mines represents a usable water resource. However, the difficulty of predicting the reliability of the resource may preclude its use in some cases. 


\section{SELECTED REFERENCES}

Alvord, Donald C., and Trent, Virgil A., 1962, Geology of the Williamson Quadrangle in Kentucky: U.S. Geological Survey Geological Quadrangle Map GQ-187, scale 1:24,000. , 1971, Geologic Maps of parts of the Naugatuck and Delbarton Quadrangles, Eastern Kentucky: U.S. Geological Survey Geologic Quadrangle Map GQ-879, scale 1:24,000.

Baker, John A., 1955, Geology and ground-water resources of the Paintsville area, Kentucky: U.S. Geological Survey Water-Supply Paper $1257,123 \mathrm{p}$.

Cassidy, Samuel M., 1973, Elements of practical coal mining: Baltimore, Maryland, American Institute of Mining, Metallurgical and Petroleum Engineering, Inc., $614 \mathrm{p}$.

Corbett, Dan M., 1965, Water supplied by coal surface mines, Pike County, Indiana: Bloomington, Indiana, Water Resources Research Center Report of Investigations No. $1,67 \mathrm{p}$.

Corbett, Dan M., and Agnew, A. F., 1968, Coal mining effect on Busseron Creek watershed, Sullivan County, Indiana: Bloomington, Indiana, Water Resources Research Center Report of Investigation No. 2 .

Currens, James C., and Smith, Gilbert E., 1977, Coal production in Kentucky, 1790-1975: Lexington, Kentucky Geological Survey, Series X, Information Circular 23, $66 \mathrm{p}$.

Davies, W. H., 1968, Engineering geology in Mineral resources of the Appalachian Region: U.S. Geological Survey Professional Paper 580, p. 91-93.

Hayes, Philip T., 1977, Geologic map of the Sitka Quadrangle, Johnson and Lawrence Counties, Kentucky: U.S. Geological Survey Geologic Quadrangle Map GQ-1398, scale 1:24,000.

Hem, John D., 1970, Study and interpretation of the chemical characteristics of natural water: U.S. Geological Survey Water-Supply Paper 1473, 2nd edition, $363 \mathrm{p}$.

Huddle, J. W., and Englund, K. J., 1962a, Geology of the Kermit Quadrangle, Kentucky: U.S. Geological Survey Geologic Quadrangle Map GQ-178, scale 1:24,000. , 1962b, Geology of the Varney Quadrangle, Kentucky: U.S. Geological Survey Geologic Quadrangle Map GQ-180, scale 1:24,000. , 1966, Geology and coal reserves of the Kermit and Varney area, Kentucky: U.S. Geological Survey Professional Paper 507, 83 p.

Jenkins, Evan C., 1966, Geologic map of the Milo Quadrangle KentuckyWest Virginia and the part of the Webb Quadrangle in Kentucky: U.S. Geological Survey Geologic Quadrangle Map GQ-543, scale $1: 24,000$.

Jillson, W. R., 1919, The Kendrick Shale, a rew calcareous fossil horizon in the coal measures of Eastern Kentucky: Kentucky Department Geology and Forestry, series 5 (of Kentucky Geological Survey), Mineral and Forest Resources Kentucky, v. 1, no. 2, p. 96-104.

Kentucky Department of Mines and Minerals, 1977-78, Annual reports: Kentucky Department of Mines and Minera1s. 
Kentucky Department for Natural Resources and Environmental Protection, Bureau of Environmental Protection, 1977, Kentucky public and semipublic water supplies regulations, (401 KAR 6-015): Division of Sanitary Engineering, Frankfort, Ky.

McFarlan, Arthur C., 1943, Geology of Kentucky: Lexington, Kentucky, The University of Kentucky, $531 \mathrm{p}$.

McGrain, Preston and Currens, James C., 1978, Topography of Kentucky: Kentucky Geological Survey, Series X, Special Publication 25, 76 p.

Morse, W. C., 1931, Pennsylvanian invertebrate fauna: Kentucky Geological Survey, series 6, v. 36, p. 293-348.

Outerbridge, William F., 1963, Geology of the Inez Quadrangle, Kentucky: U.S. Geologicay Survey Geologic Quadrangle Map GQ-226, scale 1:24,000. , 1964, Geology of the Offutt Quadrangle, Kentucky: U.S. Geological Survey Geologic Quadrangle Map GQ-348, scale 1:24,000. , 1966, Geologic map of the Paintsville Quadrangle Johnson and Floyd Counties, Kentucky: U.S. Geological Survey Geologic Quadrangle Map GQ-495, scale 1:24,000. , 1967, Geologic map of the Oil Springs Quadrangle, Eastern Kentucky: U.S. Geological Survey Geologic Quadrangle Map GQ-586, scale 1:24,000. 1976, The Magoffin Member of the Breathitt Formation in Changes in stratigraphic nomenclature by the U.S. Geological Survey, 1975: U.S. Geological 1422-A, p. 64-65.

Price, W. E., Jr., Mull, D. S., and Kilburn, Chabot, 1962, Reconnaissance of ground-water resources in the Eastern Coal Field region, Kentucky: U.S. Geological Survey Water-Supply Paper 1607, 56 p.

Rice, Charles L., 1963, Geology of the Thomas Quadrangle Kentucky: U.S. Geological Survey Geologic Quadrangle Map GQ-227, scale 1:24,000. , 1964, Geology of the Lancer Quadrangle, Kentucky: U.S. Geological Survey Geologic Quadrangle Map GQ-347, scale 1:24,000. , 1967, Geologic Map of the Prestonsburg Quadrangle, Floyd and Johnson Counties, Kentucky: U.S. Geological Survey Geologic Quadrangle Map GQ-641, scale 1:24,000.

, 1968, Geologic Map of the Redbush Quadrangle, eastern Kentucky: U.S. Geologica1 Survey Geologic Quadrangle Map GQ-708, scale 1:24,000. 1969, Geologic map of the Ivyton Quadrangle, eastern Kentucky: U.S. Geological Survey Geologic Quadrangle Map GQ-801, scale 1:24,000.

Sokal, R. R., and Rohlf, F. J., 1969, Biometry: W. H. Freeman \& Company, $776 \mathrm{p}$.

U.S. Environmental Protection Agency, 1971: Acid mine drainage formation and abatement. Water Pollution Control Research Series, Dast-42, 14010FPR 04/71, 67 p. , 1975, National interim primary drinking water regulations: Federal Register, v. 40, no. 248, p. 59566-59588.

U.S. Weather Bureau, 1977-78, Climatological data, annual summary for Kentucky: U.S. Department of Commerce. 



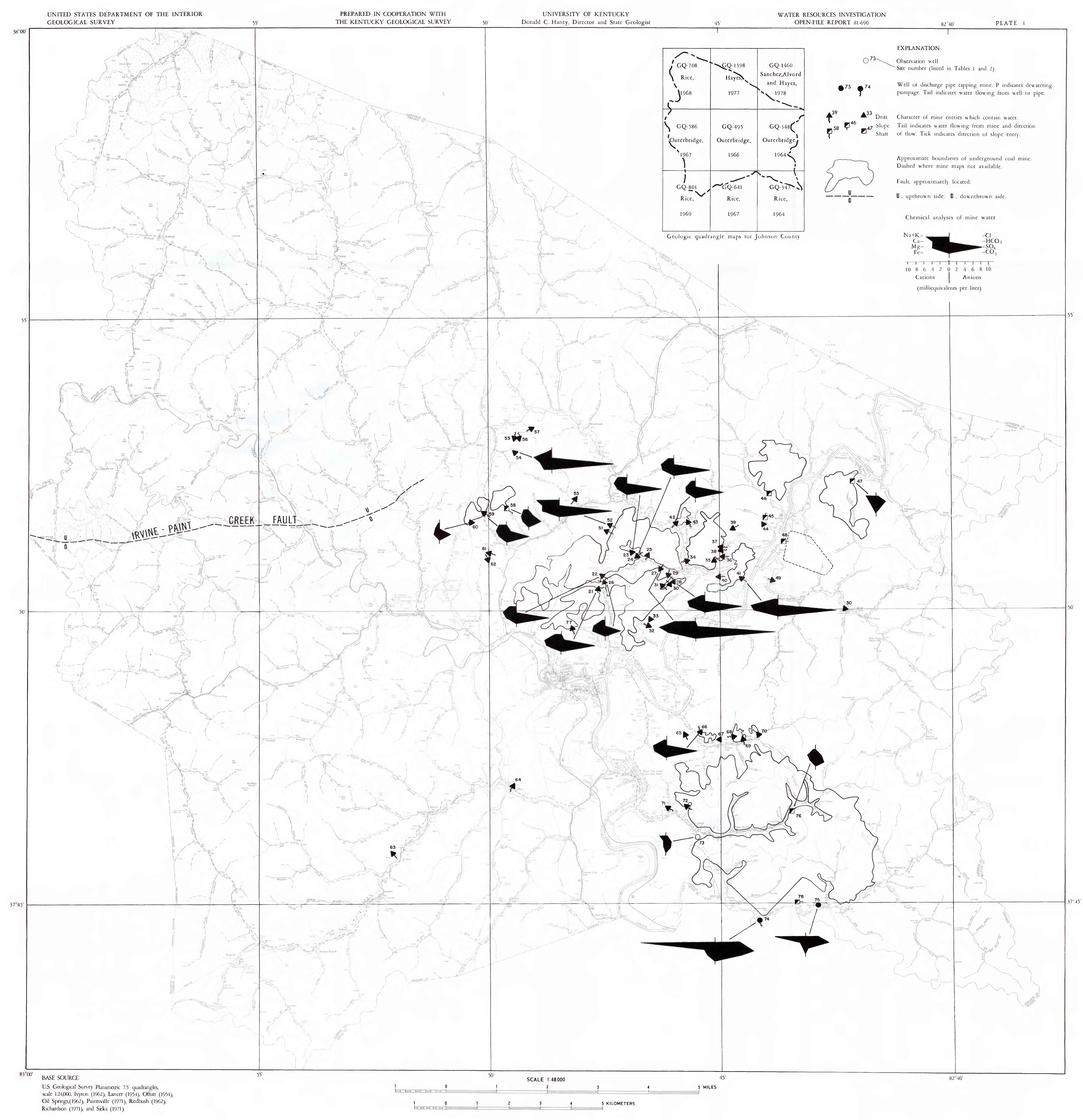

Location of coal mines, Irvine-Paint Creek Fault, and chemical character of water from selected mines in Johnson County, Kentucky. 


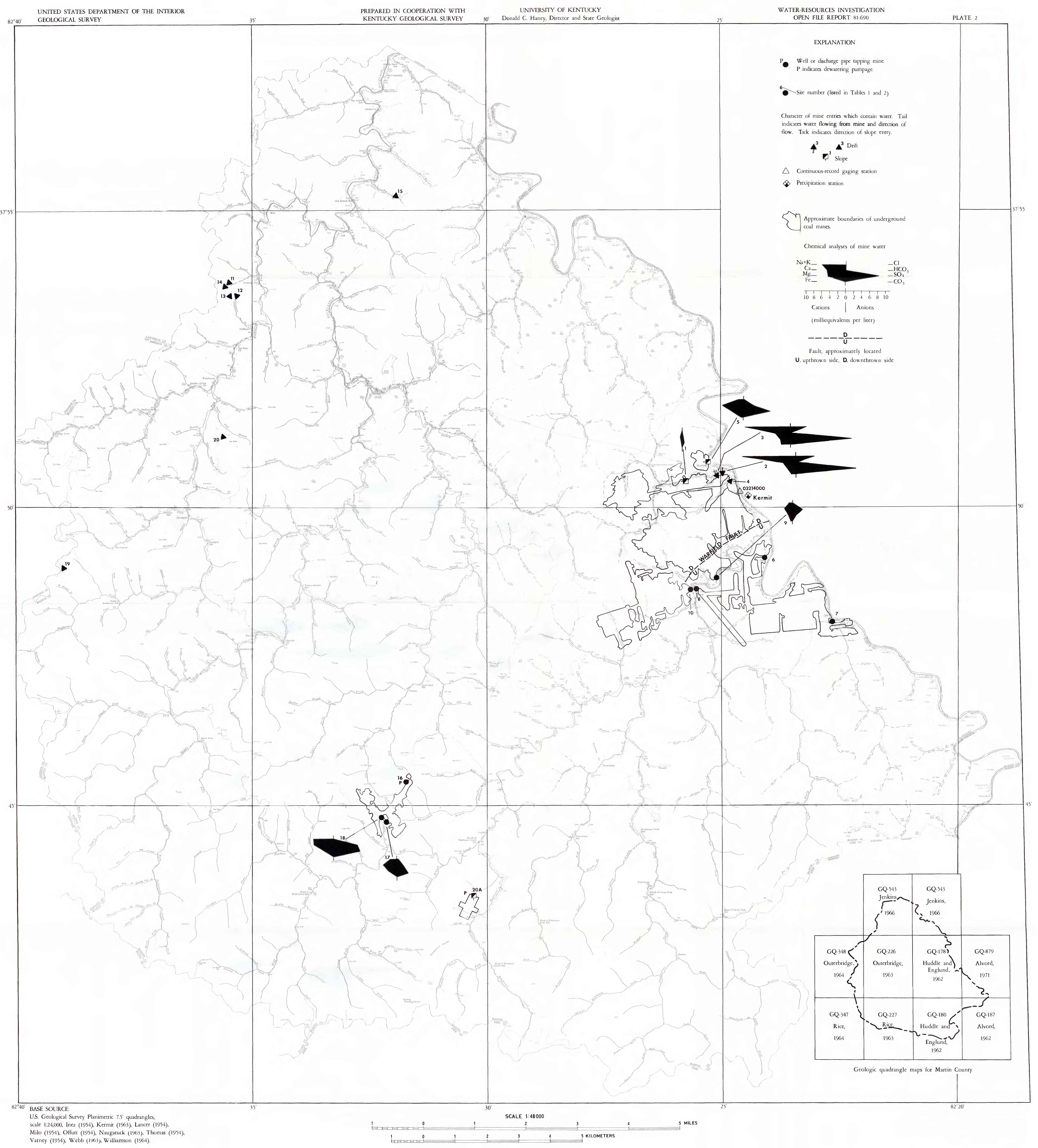


